\title{
Early gender gaps among university graduates
}

\author{
Marco Francesconi, Matthias Parey* \\ Department of Economics, University of Essex, Wivenhoe Park, Colchester CO4 3SQ United Kingdom
}

\section{A R T I C L E I N F O}

\section{Article history:}

Received 15 April 2017

Accepted 21 February 2018

Available online $\mathrm{xxx}$

\section{JEL classification:}

J16

J31

J71

\section{Keywords:}

Gender wage gap

Field of study

University graduates

Germany

\begin{abstract}
A B S T R A C T
We use data from six cohorts of university graduates in Germany to assess the extent of gender gaps in college and labor market performance twelve to eighteen months after graduation. Men and women enter college in roughly equal numbers, but more women than men complete their degrees. Women enter college with slightly better high school grades, but women leave university with slightly lower marks. Immediately following university completion, male and female full-timers work a very similar number of hours per week, but men earn more than women across the pay distribution, with an unadjusted gender gap in full-time monthly earnings of about 20 log points on average. Including a large set of controls reduces the gap to 5-10 log points. The single most important proximate factor that explains the gap is field of study at university.
\end{abstract}

(c) 2018 The Author(s). Published by Elsevier B.V. This is an open access article under the CC BY license. (http://creativecommons.org/licenses/by/4.0/)

\section{Introduction}

Since the influential survey by Altonji and Blank (1999), the economic literature has offered a variety of new explanations about gender gaps. Bertrand (2010) provides an insightful review of recent contributions, drawing on advances in the psychology and experimental literatures. Her review emphasizes the importance of gender differences in risk preferences, attitudes toward competition and negotiation, and the strength of other-regarding preferences as well as the importance of social norms that may induce differential sorting of men and women across occupations. ${ }^{1}$ In another recent survey looking at a large sample of high-income countries, Olivetti and Petrongolo (2016) stress the role played by changes in the industry structure with the shift from manufacturing to services, which might have increased female employment and reduced (but not eliminated) the gender wage gap.

\footnotetext{
We are grateful to Annette Bergemann, Sonia Bhalotra, Maru Canon, Adeline Delavande, Emilia Del Bono, George Gayle, Limor Golan, Angus Holford, Patrizia Ordine, Bob Pollak, Chiara Pronzato, Kjell Salvanes, Sarah Smith, Gerard van den Berg, Wilbert van der Klaauw, Christine Valente, and Anne Winkler for their stimulating comments and suggestions, and to seminar participants at Bristol, Calabria, Dondena Center for Research on Social Dynamics (Bocconi University), Essex, Institute for Social and Economic Research (Essex), Melbourne Institute, Statistics Norway, Washington University at St Louis, and ZEW (Mannheim). We also thank two anonymous referees for very helpful comments. We thank Kolja Briedis, Christian Kerst, Gregor Fabian, and Nicolai Netz for their help and for access to the DZHW data. Parey gratefully acknowledges the support of the ESRC Research Centre on Micro-Social Change (MiSoC) at the University of Essex.

* Corresponding author.

E-mail addresses: mfranc@essex.ac.uk (M. Francesconi), m.parey@essex.ac.uk (M. Parey).

${ }^{1}$ For a further review of the literature on existing field experiments regarding discrimination, its prevalence and consequences, see Bertrand and Duflo
} (2017). 
In this paper we revisit one of the main factors discussed by Altonji and Blank as a source of gender differentials, that is, differences in human capital accumulation. ${ }^{2}$ We follow this approach to study gender gaps in Germany, which provides an extremely interesting case for this analysis. Germany is the fourth largest economy in the world, with a highly educated population and one of the most skilled workforces (OECD, 2015). Germany also has a longstanding body of anti-discrimination laws. ${ }^{3}$ In terms of the economy, Germany has significantly increased its competiveness over recent years (Dustmann et al., 2014), At the same time, the gender pay gap remains high in international comparison. For example, OECD (2015, Fig. 13.1) shows that among OECD countries, Germany is among the countries with the highest pay gap among full-time employees (data for 2009-10).

We make use of a unique data source which allows us to analyze a representative survey of six cohorts of university graduates between 1989 and 2009 from all fields of study and across the range of Higher Education institutions in Germany, soon after they complete their college education. The survey also follows the same individuals five to six years into their careers. In this paper we focus only on the first snapshot after graduation. The reason is that career opportunities within the firm (which may involve firm-specific investment, or ability to negotiate with employers, or internal promotions) as well as other crucial family-related decisions (such as starting a family and committing resource allocations within the household) are likely to be less relevant than later on in life. ${ }^{4}$

Our results indicate that 12-18 months after graduation, the raw (unadjusted) gender gap in full-time monthly earnings is about $20 \log$ points on average, even though male and female full-timers work relatively similar hours. Including a large set of controls reduces (but does not eliminate) the gap to 5-10 log points, with the lion share in the reduction being accounted for by field of study. In light of this, assessing the extent of gender gaps and deepening our understanding of their nature within a human capital paradigm seem important steps, before looking for alternative explanations related, for example, to psychological cues, attitudes, social norms, and biomarkers.

Our analysis provides new evidence for Germany on a variety of facets of gender gaps. We consider two broad sets of outcomes. The first refers to the educational performance of men and women while they are at university and explores gender differentials in enrolment rates, marks at university entry (i.e., secondary school grades), graduation rates and graduation marks. The second set refers to early labor market performance and focuses on gender differences in the probability of having a full-time job and in pay within 12-18 months after graduation.

Existing analyses of gender gaps in Germany focus on wage differentials among all workers and not just university graduates, while gender differences in university attainments have not yet been fully explored. ${ }^{5}$ Using social security data, Fitzenberger and Wunderlich (2002) document large and persistent gaps between 1975 and 1995: they estimate that West German full-time female employees earned about 35\% less than their male counterparts at the beginning of that period, and the gap went only slightly down to about $25 \%$ at the end. These figures refer to all workers and may not apply to the most educated workforce, where censoring in the administrative data occurs frequently. In a more recent assessment with data from the 1996 Labor Force Survey, Machin and Puhani (2003) find that the (raw) gender wage difference among university graduates in Germany is about $28 \mathrm{log}$ points, and about $40 \%$ of the explained gap can be accounted for by field of study. By looking at graduates across all ages, however, these differences will in part reflect choices and constraints that emerge well after graduation.

Using data from the European Community Household Panel over the 1995-2001 period, Arulampalam et al. (2007) observe an unconditional average wage gap of $20 \%$. Conditional on covariates, they find an increasing profile of the gap along the wage distribution ranging from 6 to 17\% among public sector workers and from 14\% to 20\% among workers in the private sector. Analyzing administrative data, Huffman et al. (2017) confirm the large gaps found in the earlier studies and show that roughly half of the $29 \%$ raw gap in 2008 is accounted for by observables, including age, schooling, establishment size, collective bargaining status, and industry dummies. ${ }^{6}$

A number of institutional features specific to Germany may potentially not be gender neutral and may thus influence our outcomes of interest. ${ }^{7}$ One of such features is that Germany tracks student into different schools based on ability as

\footnotetext{
2 Although conventional human capital variables seem to explain little of the recent gender wage gap in the United States, Blau and Kahn (2017) conclude that many of the traditional explanations (driven by human capital considerations) continue to have salience.

3 This includes the constitution (Basic Law of the Federal Republic of Germany) which states that "No person shall be favored or disfavored because of sex [... ]" (Article 3(3), see Bundestag, 2017), as well as the General Equal Treatment Act from 2006 (AGG). The AGG offers protection including in relation to employment, training, occupation, and wages on the grounds of protected characteristics, one of which is gender (Federal Anti-Discrimination Agency, 2017). See also Maier (2007).

4 See, among others, Lazear and Rosen (1990), Booth et al. (2003) and Niederle and Vesterlund (2011). Of course, if men and women are forward-looking, consideration of such aspects is always important as these same aspects might shape earlier (including pre-university) decisions, beliefs, and expectations. Similarly, employers might be willing to pay male graduates more than comparable female graduates, if they anticipate that women are more likely to interrupt their careers due to family reasons (Gayle and Golan, 2012).

5 Leuze and Strauß (2009) investigate gender wage differences among German university graduates in the 1997 cohort of the DZHW, which is part of the data we analyze. However, they measure earnings differences at a later point in time in the graduates' career, and do not examine changes across cohorts.

6 With data covering the 1985-1993 period, Blau and Kahn (2003) find evidence of a fairly sizable raw gender pay gap in Germany, which goes down by about one-third when it is evaluated at U.S. values of male and female human capital characteristics. Looking at low- and medium-educated workers, Black and Spitz-Oener (2010) emphasize the role played by changes in occupational skill requirements and, in particular, the increase in the nonroutine component of work as a key factor of rising female wages: they estimate that the unconditional gender wage gap declined by about 9.3 percentage points between 1979 and 1999 and about half of the convergence can be explained by the changing structure of tasks.

7 For a comprehensive review of the recent evolution of the German economy over the period relevant to our work, see Dustmann et al. (2014).
} 
early as the end of elementary school (ages 10-12). There is evidence that early tracking has no lasting effect on later wages, employment, and occupational choice (Dustmann et al., 2017). However tracking may give differential penalties or advantages by gender (e.g., Pekkarinen, 2008 for Finland). For example, if girls mature earlier than boys during secondary school years, they could perform better in school irrespective of the track chosen, and this in turn could affect their relative performance later on, at university and in the labor market. Alternatively, more competitive boys might disproportionately attend the top school tracks, and this might in turn affect performance at university or in better-paid jobs. Our analysis will assess the extent of differential performance in secondary school among university graduates and consider whether this in turn has an impact on outcomes.

Another feature is that, since the late 1970s, Germany has also developed (and provided working mothers with) generous maternity leave coverage, whereby mothers are currently eligible for three years of partially paid leave. Analyzing the impact of five major expansions in maternity leave coverage occurred between 1979 and 1993, Schönberg and Ludsteck (2014) find that the impact of such expansions on overall maternal employment, employer continuity, and labor market income 3-6 years after childbirth is small. The small magnitude of the impact could be the result of pre-labor market selections, either into school track or field of study and occupation. In our work, we focus on the role of decisions and human capital accumulation inside the university and education system, such as field of study.

Our work is related to a number of existing studies which focus on highly skilled individuals, primarily in the United States. Bertrand et al. (2010) study the careers of men and women who gained a master's degree in business administration (MBA) from a top US business school between 1990 and 2006. They find that, 10-16 years after MBA completion, the male (unadjusted) earnings advantage is nearly $60 \mathrm{log}$ points. Differences in business school courses and grades, differences in career interruptions and differences in weekly hours worked are identified as the three most important explanations for the large and rising gender gap. Interestingly, important differences are observed also at the outset of men and women's careers. One year after MBA completion, men earn approximately 15\% more than women. Although the gap goes down to about $6 \%$ after controlling for a large set of characteristics (e.g., pre-MBA characteristics, MBA performance, labor market experience, and weekly hours), it remains statistically significant. Looking at pharmacists, Goldin and Katz (2016) find that conditioning on hours of work reduces the gender earnings gap from about $28 \%$ to $4 \%-7 \%$. Among those without children, female pharmacists earn only $1 \%$ less than comparable male pharmacists, and this difference is not statistically significant. It is unlikely, however, that this pattern is observed across the range of other professional occupations, and it is part of our objectives to explore this for Germany. ${ }^{8}$

Two recent studies look at the experience of countries other than the United States. Building on the previous work by Albrecht et al. (2003), the first study is by Albrecht et al. (2017). They analyze Swedish matched employer-employee data on men and women born in the 1960s who completed their university education in business and economics and are followed for 20 years after graduation. ${ }^{9}$ At the start of their careers, at age of 25-26 years, men and women have virtually the same monthly full-time equivalent wages, but by age 45 there is a sizeable gender wage gap of about 25 log points. Albrecht et al. (2017) argue that, over and above the differences in firm characteristics and firm-to-firm mobility by gender, the main driver of the gap appears to be the greater wage gains experienced by men as opposed to women.

The second study by Bütikofer et al. (2017) looks at Norway. Using detailed register data, they focus on the effect of parenthood on the careers of men and women with MBA, law, medical, and STEM degrees. ${ }^{10}$ They show that, among top earners, the share of women holding a degree in all subjects, except medics, has increased substantially since the mid 1980 s. Interestingly, when focusing on men and women at the start of their careers, the average earnings prior to childbirth are identical in levels for men and women. As illustrated by Bertrand et al. (2010) for American MBAs, also in Norway differences in career interruptions that are associated with childbirth lead to substantial pay gaps by gender, which do not decline even ten years after childbirth. ${ }^{11}$ Comparing to our findings, our results indicate that the differentials faced by young German male and female college graduates are somewhere in between those faced by their American and Scandinavian counterparts.

Section 2 describes our main data source. Section 3 presents the main results related to gender gaps at entry into, and exit from, university. Section 4 discusses the estimates found in relation to gender gaps in the labor market. Finally,

\footnotetext{
8 Using data from different cohorts of Harvard graduates who graduated in the early 1970s, early 1980s, and early 1990s, Goldin and Katz (2008) find a staggering raw gender gap in earnings of more than $80 \mathrm{log}$ points. This goes down to 30 log points after a host of characteristics are controlled for, including weeks and hours worked, major and graduate degrees, nonwork, and occupational dummies. The large gap could reflect the fact that earnings are measured in 2005, implying a minimum of 13 (32) years have elapsed since graduation for the youngest (oldest) cohort. We do not know the extent of the gap soon after graduation. With data from the Young Physician's Survey that follows a sample of physicians from two to nine years after residency, Sasser (2005) finds that female physicians who are unmarried and without children earn about $20 \%$ less than men on an annual basis and about $10 \%$ less in terms of hourly pay. But again, during the nine years after residency, many decisions could be taken to affect earnings profiles and labor market performance differently between women and men. For a sample of law school graduates from the University of Michigan, Wood, Corcoran, and Courant (1993) report that women earn $93 \%$ as much as men in the first year after graduation and that this gap widens over time, with women earning about $60 \%$ of their male counterparts 15 years after graduation.

9 One of the striking results emphasized by Albrecht et al. (2003) is that gender (log) wage gap in Sweden increases throughout the wage distribution and accelerates in the upper tail, above the seventy-fifth or eightieth percentile in the wage distribution.

10 STEM stands for Science, Technology, Engineering, and Mathematics subjects.

11 Fitzenberger et al. (2013) investigate the long-run effect of child birth on gender differences in employment in Germany in a dynamic treatment framework. Adda et al. (2017) study the interaction between fertility and occupational choice in a dynamic life-cycle model.
} 
Section 5 summarizes our main findings, contrasts them with the existing literature, and puts forward a number of areas for future work.

\section{Data}

We analyze the trajectories of college graduates using survey data collected by the German Centre for Higher Education Research and Science Studies (DZHW). These data come from nationally representative longitudinal surveys of individuals who complete their university education across all fields of studies and the full range of Higher Education institutions in Germany. ${ }^{12}$

The DZHW sampled university graduates from the graduation cohorts 1988-89, 1992-93, 1996-97, 2000-01, 2004-05, and 2008-09. ${ }^{13}$ This gives us a large sample of high-skilled individuals spanning a 20-year period. For each graduation cohort, individuals are first interviewed about 12-18 months after graduation. The same individuals also participate in a second, follow-up survey about five years after graduation (see Appendix Fig. A.1). In our analysis we focus only on the first survey: as we have explained above, this allows us to abstract from crucial decisions other than those related to early careers (e.g., family formation and fertility choices) and from later career opportunities (which involve internal promotions and negotiation with employers).

Each survey contains detailed information on graduates' personal characteristics, family background, study history, and labor market experience. For each graduate, we observe the university attended and the field of study completed. ${ }^{14}$ We complement this information with administrative data published by the German Federal Statistical Office.

Although the DZHW data have been gathered systematically across cohorts, there are some differences in the information available across the cohorts. For instance, information on marks from the exams (known as Abitur) taken at the end of the academically oriented secondary school track (Gymnasium) are not available for the 1989 cohort. We therefore present two sets of estimates, either excluding the 1989 cohort or dropping the secondary school mark variable from the analysis.

Table 1 reports the summary statistics of key variables from the DZHW data. High school marks are scored on an approximately continuous scale from 1 to 4 , where 1 is the top score and 4 is the lowest passing mark. On average, across all cohorts, female graduates enter university with a slightly better mark, showing a gap of 0.065 points which is statistically significantly different from zero at conventional levels and represents about $10 \%$ of a standard deviation. University final score is measured on the same scale, with 1 and 4 meaning top and lowest passing marks, respectively. At the end of their university career, women also graduate with slightly better marks than men across all cohorts (again statistically significant). However, as we document in our subsequent analysis, these aggregate average statistics conceal heterogeneity across cohorts.

About $87 \%$ of females and $88 \%$ of males have ever been in any kind of employment since graduation and up to the survey. Between 12 to 18 months since graduation, about $71 \%$ of women are in paid full-time employment (relative to part-time employment), as opposed to $81 \%$ of men. The large 10 percentage point difference is statistically significant. Among full-timers, the mean number of hours worked per week is around 40, with no significant difference between men and women. Average full-time monthly log earnings (excluding additional bonuses or variable pay) are 7.587 (corresponding to just below 2000 Euros, measured in 2001 prices) for all workers across all graduation cohorts, with men earning 28.3 log points (or nearly one-third) more than women. ${ }^{15}$ This difference is statistically significant. In terms of median earnings (not reported in the table), the members of the 2009 DZHW cohort have median monthly earnings of 1747 Euros for women and 2329 Euros for men (including full-time and part-time workers). Among full-time workers, median earnings in the 2009 cohort are 2183 and 2620 Euros for women and men, respectively (in 2001 prices).

At the time of interview, men are older, suggesting that women tend to obtain their degrees earlier than men. ${ }^{16}$ It is worth noticing that male and female graduates are also different along a number of other observable, predetermined characteristics. For instance, almost one-third of men have completed an apprenticeship before starting their degree, as opposed to only one-quarter of women. Moreover, compared to their male counterparts, female graduates have parents (both mothers and fathers) with substantially higher education, greater labor market involvement, and in higher-level occupations. For example, female graduates' mothers have on average almost 0.9 more years of education, compared to their male counterparts (which partly reflects time trends in share of females and parental education).

\footnotetext{
12 For further details see Grotheer et al. (2012). See also Parey and Waldinger (2011) and Parey et al. (2017) for further details on the data.

13 We refer to the cohorts by the second year, i.e. 1989 for the $1988-89$ cohort.

14 For our analysis, degree subjects are classified at the 2-digit level, with around 60 distinct fields of study. Due to data availability, 'university attended' in our analysis refers to the institution where the individual first enrolled. For a subset of the data we also observe the institution where the degree was completed, and we obtain very similar results between the two specifications for these cohorts.

15 This statistic is for the sample of all graduates in full-time employment; graduates who are in a further training are not excluded as long as they hold a full-time employment contract.

16 With graduation occurring up to 18 months before the interview, individuals complete their university studies at about $26-27$ years of age on average. This is high in comparison to the experience of British and American students, among others. In part, this relates to the traditionally different degree structure in Germany (Diplom and Staatsexamen). After the introduction of Bachelor and Master degrees in Germany, the survey includes graduates from both Bachelor and Master programs and we pool these two groups. The gender difference in age represents in part the effect of compulsory military service (or alternative community service).
} 
Table 1

Summary statistics.

\begin{tabular}{|c|c|c|c|c|}
\hline Female & $\begin{array}{l}\text { All } \\
\text { Mean } \\
\text { (st. dev.) } \\
0.483\end{array}$ & $\begin{array}{l}\text { Female } \\
\text { Mean } \\
\text { (st. dev.) } \\
1\end{array}$ & $\begin{array}{l}\text { Male } \\
\text { Mean } \\
\text { (st. dev.) } \\
0\end{array}$ & $\begin{array}{l}t \text {-test } \\
p \text {-value }\end{array}$ \\
\hline Log monthly earnings ${ }^{a}$ & $\begin{array}{l}7.587 \\
(0.501)\end{array}$ & $\begin{array}{l}7.429 \\
(0.509)\end{array}$ & $\begin{array}{l}7.711 \\
(0.457)\end{array}$ & 0.000 \\
\hline Hours worked per week ${ }^{b}$ & $\begin{array}{l}40.068 \\
(3.260)\end{array}$ & $\begin{array}{l}40.003 \\
(2.956)\end{array}$ & $\begin{array}{l}40.162 \\
(3.657)\end{array}$ & 0.129 \\
\hline Full-time employment ${ }^{c}$ & 0.763 & 0.712 & 0.809 & 0.000 \\
\hline Ever employed since graduation $^{\mathrm{d}}$ & 0.874 & 0.872 & 0.878 & 0.000 \\
\hline $\begin{array}{l}\text { Final secondary school grade } \mathrm{e}^{\mathrm{a}} \\
\text { (Abitur) }\end{array}$ & $\begin{array}{l}2.233 \\
(0.630)\end{array}$ & $\begin{array}{l}2.201 \\
(0.615)\end{array}$ & $\begin{array}{l}2.266 \\
(0.643)\end{array}$ & 0.000 \\
\hline Final university grade & $\begin{array}{l}2.019 \\
(0.677)\end{array}$ & $\begin{array}{l}2.002 \\
(0.670)\end{array}$ & $\begin{array}{l}2.035 \\
(0.682)\end{array}$ & 0.000 \\
\hline High graduation mark ${ }^{\mathrm{f}}$ & 0.255 & 0.264 & 0.247 & 0.000 \\
\hline Age at survey & $\begin{array}{l}28.018 \\
(3.170)\end{array}$ & $\begin{array}{l}27.687 \\
(3.541)\end{array}$ & $\begin{array}{l}28.327 \\
(2.743)\end{array}$ & 0.000 \\
\hline Apprenticeship & 0.292 & 0.254 & 0.328 & 0.000 \\
\hline Mother's education (years) & $\begin{array}{l}12.699 \\
(3.361)\end{array}$ & $\begin{array}{l}13.147 \\
(3.337)\end{array}$ & $\begin{array}{l}12.28 \\
(3.328)\end{array}$ & 0.000 \\
\hline Father's education (years) & $\begin{array}{l}13.976 \\
(3.545)\end{array}$ & $\begin{array}{l}14.354 \\
(3.429)\end{array}$ & $\begin{array}{l}13.623 \\
(3.615)\end{array}$ & 0.000 \\
\hline Mother self-employed & 0.099 & 0.107 & 0.091 & 0.000 \\
\hline Mother salaried employee & 0.526 & 0.57 & 0.484 & 0.000 \\
\hline Mother civil servant & 0.083 & 0.094 & 0.073 & 0.000 \\
\hline Mother blue-collar worker & 0.098 & 0.082 & 0.114 & 0.000 \\
\hline Mother did not work & 0.194 & 0.147 & 0.238 & 0.000 \\
\hline Father self-employed & 0.209 & 0.224 & 0.196 & 0.000 \\
\hline Father salaried employee & 0.424 & 0.436 & 0.413 & 0.000 \\
\hline Father civil servant & 0.192 & 0.192 & 0.192 & 0.999 \\
\hline Father blue-collar worker & 0.134 & 0.122 & 0.145 & 0.000 \\
\hline Father did not work & 0.040 & 0.025 & 0.054 & 0.000 \\
\hline$N$ & 54,108 & 26,153 & 27,955 & \\
\hline
\end{tabular}

Note: Table displays means and standard deviations of selected variables ( $N$ denotes number of graduates). (a): conditional on full-time employment in Germany. $N($ all $)=28,125, N($ female $)=12,576, N($ male $)=15,549$. (b): For full-time workers; this hours measure is only available in 2009. $N($ all $)=3,793$, $N($ female $)=2,234, N($ male $)=1,559$. (c): Full-time employment here is an indicator, taking the value 1 for individuals in full-time employment, and 0 for part-time. $N($ all $)=44,289, N($ female $)=21,011, N($ male $)=23,278$. (d): Cohorts 2001, 2005, 2009, $N($ all $)=25,321, N($ female $)=14,957, N($ male $)=10,364$. (e): $N($ all $)=42,309, N($ female $)=21,725, N($ male $)=20,584$. (f): 'High graduation mark' refers to a mark of 1.5 or less (note reverse scale, lower marks mean better performance). Own calculations based on DZHW data. See text for details.

\section{Gender gaps in university education}

To see if there are compositional differences in university education we first analyze enrolment rates by sex. We then look at potential gender differences in "quality" at entry into college, which we proxy with the Abitur grades obtained before starting a university program. Next, we consider the possibility of differential graduation rates by sex, since those who complete their program of study should be more likely to be in graduate employment than those who do not complete. Finally, we look at gender gaps in graduation marks, which are taken as a indicator of quality of the university qualification attained and could be a relevant proxy (for ability or productivity) which is easily observed by employers.

\subsection{Gaps in the quantity at entry: enrolment numbers}

There might be a "quantity" imbalance at entry, that is, differential female-male enrollment into university courses. To explore this possibility, we investigate enrollment counts by gender, using aggregate administrative data on university enrollment. ${ }^{17}$

Fig. 1 shows the trends from 1947 to 2015. From the beginning of the period to 1989, the data refer to the former West Germany only, while from 1990 onwards the data has coverage of the whole of Germany, including the former German Democratic Republic. From the post-WWII period to the early 1990s, substantially more men than women entered a college program, with a female-to-male student ratio of 0.4-0.6. By 1995 and up to the most recent data point, however, the

\footnotetext{
${ }^{17}$ Here, we focus on first enrollment in higher education. These data include enrollment into traditional universities as well as universities of applied science (Fachhochschulen), comprehensive universities (Gesamthochschulen), theological higher education institutions (Kirchliche Hochschulen), and higher education institutions for public administration (Verwaltungsfachhochschulen).
} 


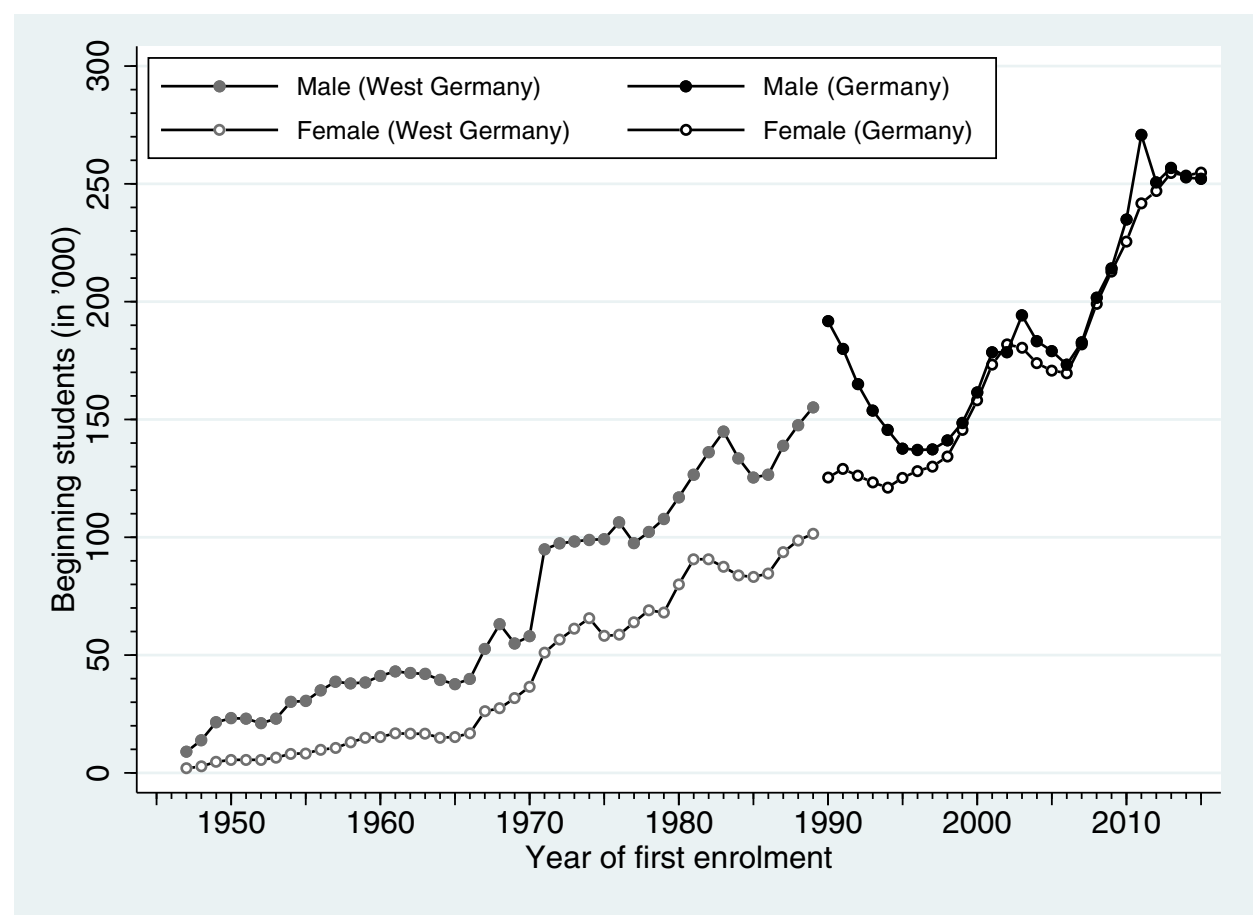

Fig. 1. Enrolment count. Source: Destatis (2017). Note: Shows number of students enrolling for the first time in Higher Education. Year refers to academic year (e.g., 1998 includes winter term 1998/99 and subsequent summer term).

numbers have become very similar. ${ }^{18}$ The share of females enrolled has therefore steadily increased since 1995 , from a ratio of 0.91 per male student, and reaching parity in 2015, when we observe a ratio of 1.002 .

\subsection{Gaps in the quality at entry: high school grades}

New male entrants into post-secondary education institutions may have greater high school marks than their female counterparts. We assess this possibility by looking at gender differences in Abitur grades, conditional on having obtained a degree. Grades range between 1 (top) and 4 (lowest passing grade) on an approximately continuous scale. The pooled mean of 2.23 and standard deviation of 0.63 have remained fairly constant across cohorts and the cohort-specific distributions are also relatively similar.

Panel A in Table 2 reports the female coefficient from a series of regressions. In the first row, we only control for cohort dummies; while in the second we also include apprenticeship status, and family background variables (all predetermined characteristics at the time of university enrollment) as well as age, and in the third we further control for subject and university fixed effects. Notice that a negative sign means that women have a better mark than men, because values are on a reverse scale.

Across all graduation cohorts, women enter university with slightly better high school marks (row (i)). The size of the uncorrected gap is 0.069 (or about 0.11 of a standard deviation in high school score). Correcting for predetermined characteristics reduces the gap to 0.015 (or 0.02 of a standard deviation, row (ii)). In fact, men in the earlier cohorts (1993 and 1997) have better marks, corresponding to a period when also more of them enrolled (see Fig. 1): in such cases, the size of the gender gap is about 0.05 (0.07-0.08 of a standard deviation). But from 2005 onwards, women have substantially higher entry marks, of the order of $0.12-0.13$ of a standard deviation. This 'overtaking' is a phenomenon also highlighted by Fortin et al. (2015) for the United States, although in our case we consider only individuals who actually enroll at university and complete their university studies, and not all secondary school students.

Controlling for field of study and institution fixed effects leads to a gap of about 0.07 of a standard deviation across all subjects (row (iii)). Panel B of Table 2 shows there is heterogeneity across specific degree areas, although the broad pattern emerges within each field. Among those who enroll in medical sciences and economics/business, women tend to have better secondary school marks. This is not the case among those who enroll in STEM (which are typically male dominated) and humanities subjects (which are typically female dominated).

${ }^{18}$ There are two exceptions in which we observe a slightly greater number of men enrolled, i.e., 2003 and 2011. In 2011, military conscription for males was suspended. 
Table 2

Entrants' quality: gender differences in high school marks, by cohort.

\begin{tabular}{|c|c|c|c|c|c|c|c|}
\hline $\begin{array}{l}\text { Field of } \\
\text { study }\end{array}$ & Controls $\backslash$ Year & All & 1993 & 1997 & 2001 & 2005 & 2009 \\
\hline \multicolumn{8}{|c|}{ A. All subjects } \\
\hline (i) All & Cohort FE & $\begin{array}{l}-0.069 \\
(0.006)^{* * *}\end{array}$ & $\begin{array}{l}-0.024 \\
(0.014)^{*}\end{array}$ & $\begin{array}{l}-0.019 \\
(0.014)\end{array}$ & $\begin{array}{l}-0.070 \\
(0.015)^{* * *}\end{array}$ & $\begin{array}{l}-0.116 \\
(0.012)^{* * *}\end{array}$ & $\begin{array}{l}-0.112 \\
(0.014)^{* * *}\end{array}$ \\
\hline (ii) All & $\begin{array}{l}\text { Cohort FE, family } \\
\text { Background }\end{array}$ & $\begin{array}{l}-0.015 \\
(0.006)^{* *}\end{array}$ & $\begin{array}{l}0.053 \\
(0.013)^{* * *}\end{array}$ & $\begin{array}{l}0.046 \\
(0.014)^{* *}\end{array}$ & $\begin{array}{l}-0.009 \\
(0.015)\end{array}$ & $\begin{array}{l}-0.074 \\
(0.012)^{* * *}\end{array}$ & $\begin{array}{l}-0.080 \\
(0.014)^{* * *}\end{array}$ \\
\hline (iii) All & $\begin{array}{l}\text { Cohort FE, family } \\
\text { Background, } \\
\text { Subject FE, uni FE }\end{array}$ & $\begin{array}{l}-0.045 \\
(0.006)^{* * *}\end{array}$ & $\begin{array}{l}0.003 \\
(0.014)\end{array}$ & $\begin{array}{l}-0.004 \\
(0.015)\end{array}$ & $\begin{array}{l}-0.055 \\
(0.016)^{* * *}\end{array}$ & $\begin{array}{l}-0.075 \\
(0.013)^{* * *}\end{array}$ & $\begin{array}{l}-0.088 \\
(0.015)^{* * *}\end{array}$ \\
\hline \multirow{2}{*}{\multicolumn{2}{|c|}{$\begin{array}{l}N \\
\text { Share female }\end{array}$}} & 42,651 & 9494 & 8114 & 7048 & 9963 & 8032 \\
\hline & & 0.515 & 0.385 & 0.433 & 0.592 & 0.577 & 0.604 \\
\hline \multicolumn{8}{|c|}{ B. By selected subject groups } \\
\hline \multirow{4}{*}{$\begin{array}{l}\text { (iv) } \\
\text { Economics } \\
\text { / Business }\end{array}$} & Cohort FE, family & -0.108 & -0.005 & -0.120 & -0.130 & -0.103 & -0.125 \\
\hline & Background, & $(0.016)^{* * *}$ & $(0.039)$ & $(0.034)^{* * *}$ & $(0.044)^{* *}$ & $(0.033)^{* *}$ & $(0.031)^{* * *}$ \\
\hline & Subject FE, uni FE & 5615 & 1014 & 1163 & 743 & 1310 & 1385 \\
\hline & Cohort FE, family & 0.019 & 0.059 & 0.070 & -0.003 & 0.004 & -0.009 \\
\hline \multirow[t]{2}{*}{ (v) STEM } & Background, & $(0.013)$ & $(0.029)^{* *}$ & $(0.032)^{* *}$ & $(0.030)$ & $(0.030)$ & $(0.035)$ \\
\hline & Subject FE, uni FE & 11826 & 3209 & 2562 & 2167 & 2232 & 1656 \\
\hline \multirow{3}{*}{$\begin{array}{l}\text { (vi) } \\
\text { Humanities }\end{array}$} & Cohort FE, family & 0.039 & 0.137 & -0.027 & -0.030 & 0.155 & -0.073 \\
\hline & Background, & -0.029 & $(0.068)^{* *}$ & $(0.067)$ & $(0.072)$ & $(0.062)^{* *}$ & $(0.069)$ \\
\hline & Subject FE, uni FE & 3003 & 548 & 565 & 495 & 806 & 589 \\
\hline \multirow{3}{*}{$\begin{array}{l}\text { (vii) } \\
\text { Medical } \\
\text { Studies }\end{array}$} & Cohort FE, family & -0.050 & -0.034 & 0.070 & -0.037 & -0.074 & -0.154 \\
\hline & Background, & $(0.022)^{* *}$ & $(0.041)$ & $(0.056)$ & $(0.057)$ & $(0.046)$ & $(0.052)^{* *}$ \\
\hline & Subject FE, uni FE & 2563 & 751 & 442 & 416 & 576 & 378 \\
\hline
\end{tabular}

Note: Grades are in reverse scale, so that negative coefficient means women have a better high-school mark than their male counterparts. Marks are on a scale from 1.0 (best mark) to 4.0 (worst passing mark). In 1989, information on high-school marks was not collected. Numbers reported are regression coefficient on 'Female' dummy, with additional controls as indicated. Degree subject groups: the group called 'Humanities' includes literature, language, and philosophy, while 'Medical studies' includes medicine, dentistry, and pharmacy. Numbers reported in each cell (from top to bottom) are coefficient, standard error, number of observations, and (in italics) share of females among graduates (in panel B).

In summary, our starting point is to assess whether there are gender differences when men and women start their university careers, over the period that pertains the DZHW data. There is a greater fraction of men enrolling at university up to the mid 1990s, when men also had a small advantage in terms of quality at entry. In the most recent data, however, women and men enter college in equal numbers and female graduates begin their university careers with slightly better high school marks.

\subsection{Gaps in the quantity at exit: graduation numbers}

We now move to the end of the university process and focus on two graduation outcomes. We first consider whether there are differences in the quantity of female graduates as opposed to male graduates.

To describe the time trends in the numbers of male and female graduates, we use administrative data on the number of graduates by field of study. Fig. 2 reports the raw numbers, while Fig. 3 shows the corresponding female/male ratios. From the early 1990s to the mid 2010s, the total number of graduates has gone up from 181,000 in 1993-339,000 in 2015 (see panel (a) in Fig. 2), implying an increase of about $87 \%$ over the period (an average increase of nearly $4 \%$ every year). The share of all graduates represented by women has also increased from about 40\% in 1993 to approximately 52\% in 2015, or equivalently from a female/male ratio of 0.66 to a ratio of 1.09 (see Fig. 3).

Some fields of study, such as fine art, art history, and humanities (including foreign languages), have been traditionally female dominated, with $60-70 \%$ of graduates in the mid 1990s being women. Over time, they have become even more female dominated, with 65\%-75\% of graduates being women in 2015 (see panels (c) and (f) in Fig. 2). Conversely, other fields-such as science, technology, engineering, and mathematics (STEM)-were male dominated in the 1990s and continue to be so in the 2010s, although the share of all graduates represented by women has increased from about $15 \%$ to almost $25 \%$ in engineering and computing and from around $35 \%$ to $40 \%$ in all hard sciences and mathematics (see panels (d) and (g) in Fig. 2).

Clear increases for women in graduation rates can be observed in health sciences (including medicine and pharmacy), social sciences (including law, business studies, economics and psychology), and agricultural studies (including nutrition science). In the first two areas of study, in particular, the growth in the number of female graduates has been quite remarkable (see panels (e) and (h) respectively in Fig. 2, as well as Fig. 3): up by about 12 points in the case of social sciences (from $44 \%$ to $56 \%$ of all graduates) and up by nearly one quarter in the case of health sciences (from $45 \%$ to almost $70 \%$ ). 
(a) All subjects

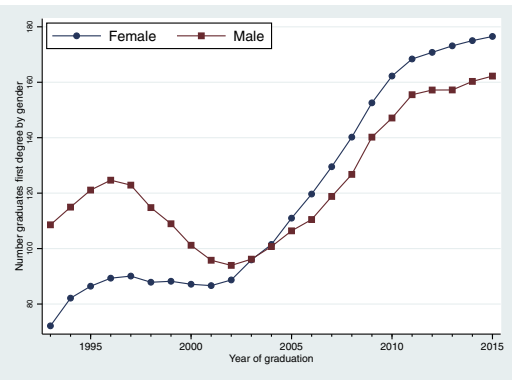

(d) Engineering

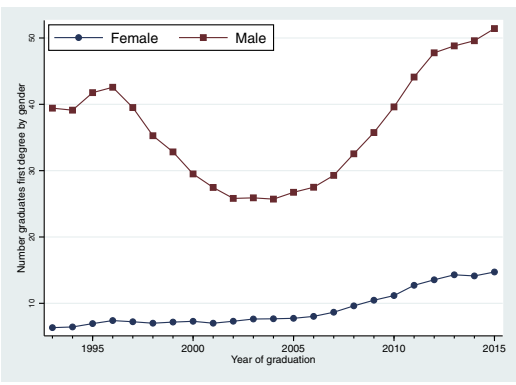

(g) Math, natural sciences

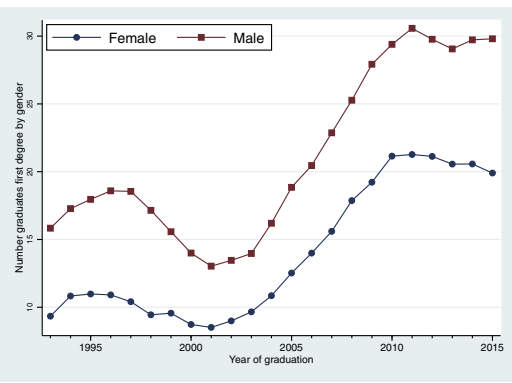

(b) Agric., forestry, nutrition studies

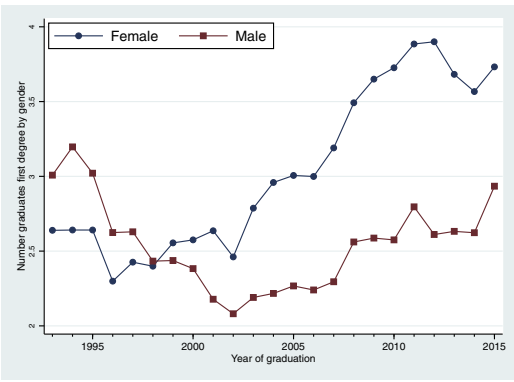

(e) Medicine, health science

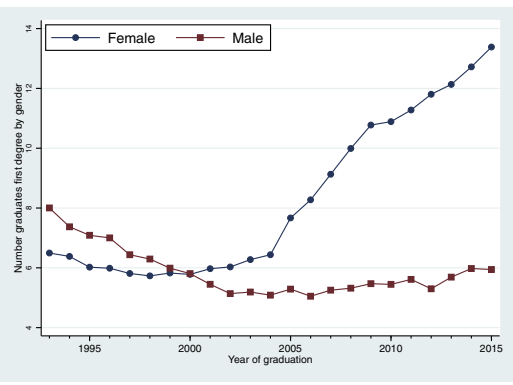

(h) Law, economics, social science

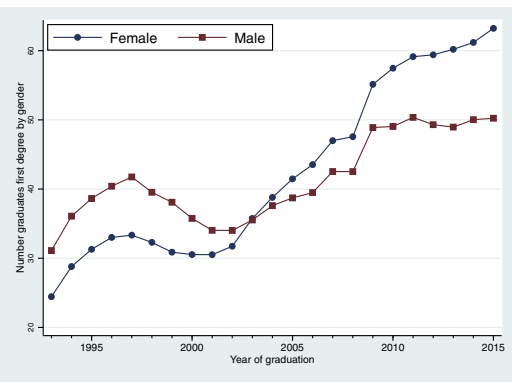

(c) Art, art science

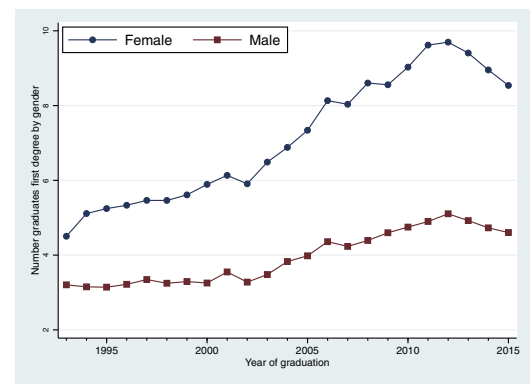

(f) Language, cultural studies

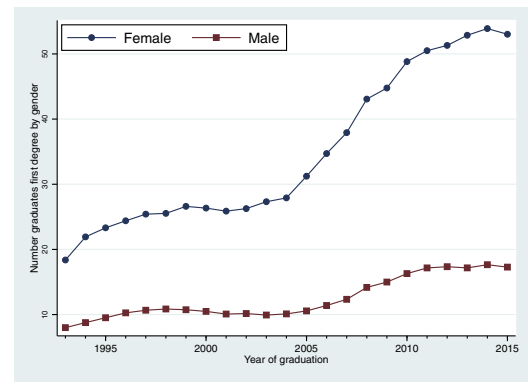

Fig. 2. Trends in graduate counts, by field of study. Source: BMBF (2017). Note: Scales differ across figures. Number of graduates is measured in 1,000.

Notice that both the time trend over our sample period and the actual fraction of female graduates in all health science programs in Germany are very similar to those shown by Goldin and Katz (2016) for pharmacists in the United States.

\subsection{Gaps in the quality at exit: graduation grades}

A second outcome at exit is degree quality, which is measured by the final graduation mark. To assess whether there are gender gaps in grade performance, we use data from across the six DZHW cohorts and perform three different exercises.

Means. In the first exercise we estimate five different specifications of a final grade equation, keeping in mind that marks range from 1.0 (best) to 4.0 (worst passing mark), and thus a positive sign indicates lower marks for female graduates. Using data pooled across five cohorts (excluding 1989) and with a regression that controls for survey wave dummies, we find a small (but statistically significant) gender gap at 0.022 points (s.e.=0.006) that favors men (see column (a) of Table 3). This difference corresponds to just 0.032 of the sample grade standard deviation. The addition of demographic and socioeconomic controls to the regression increases the gender gap to 0.04 points (column (b)), suggesting that the lower marks obtained by women are unlikely to reflect differences in socio-demographic and family background variables.

Adding high school marks, field of study fixed effects, and university fixed effects (columns (c)-(e)) leads to gradually higher gender gaps reaching 0.063 points (column (e)), which corresponds to 0.09 of a standard deviation. These estimates demonstrate that conditioning on covariates to control for differences in individual characteristics and family background, high school results, subject of study, and university attended does not eliminate the small grade gender gap that favors men over women. In fact, if anything, such differences magnify the grade gender gap, although this remains arguably modest. These patterns are in line with the descriptives presented in Table 1 above. 


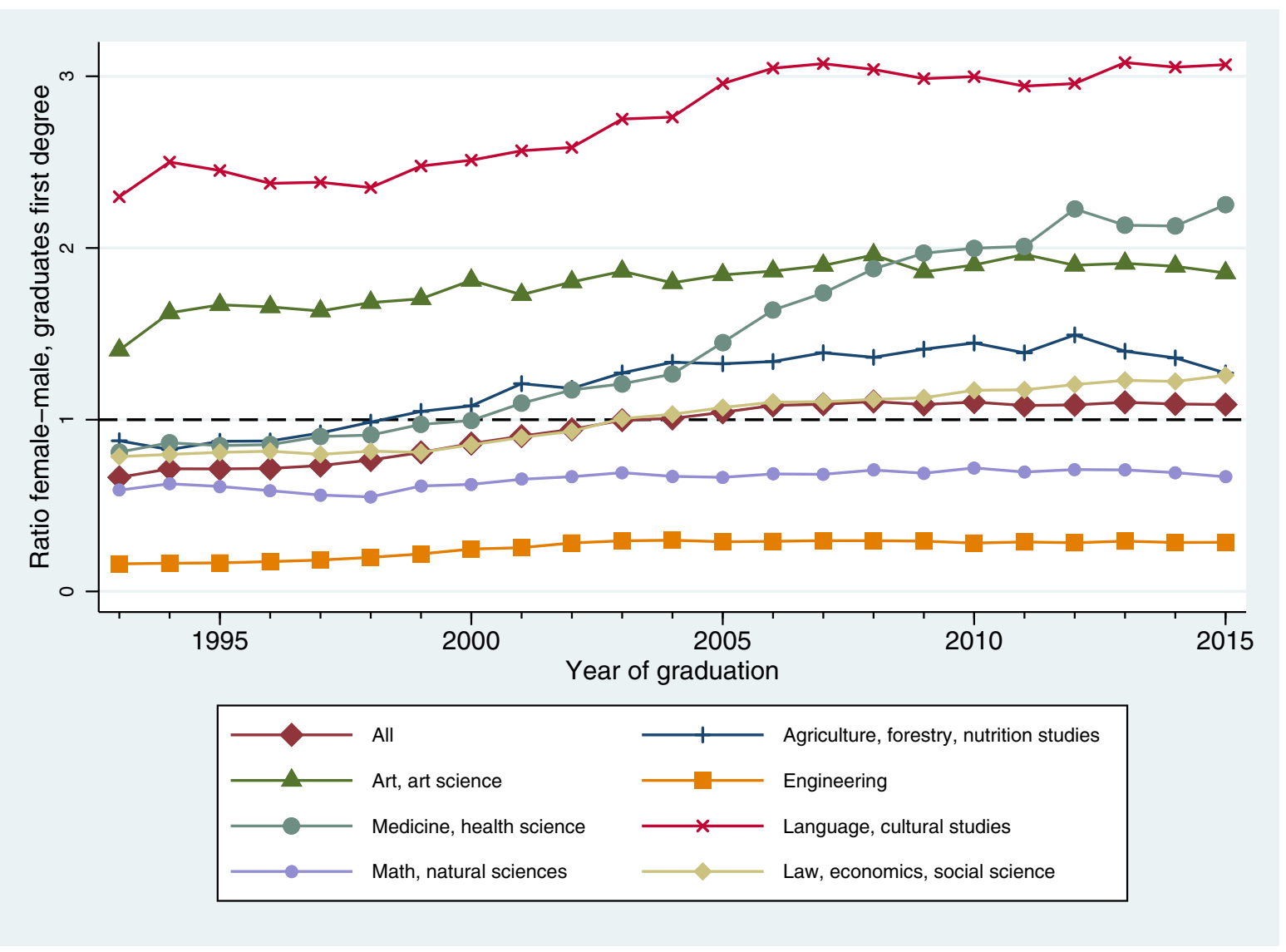

Fig. 3. Gender ratio among graduates, by field of study. Source: BMBF (2017).

Table 3

Gender differences in university graduation marks, by specification.

\begin{tabular}{llllll}
\hline & (a) & (b) & (c) & (d) & $(\mathrm{e})$ \\
\hline Female & 0.022 & 0.041 & 0.044 & 0.058 & $(0.006)^{* * *}$ \\
$N$ & $(0.006)^{* * *}$ & $(0.007)^{* * *}$ & $(0.006) * * *$ & $(0.006)^{* * *}$ \\
$N$ & 42,651 & 42,651 & 42,651 & 42,651 & Y,65 \\
Cohort FE & YES & YES & YES & YES \\
Age, family background & NO & YES & YES & YES & YES \\
Final secondary school grade & NO & NO & YES & YES \\
Field of study FE & NO & NO & NO & YES \\
University FE & NO & NO & NO & NO \\
\hline
\end{tabular}

Note: Dependent variable is final university grade. Grades are in reverse scale, so that a negative coefficient means women have a better final university mark than their male counterparts. Marks are on a scale from 1.0 (best mark) to 4.0 (worst passing mark). Same sample as in Table 2, Panel A. In 1989 , information on high-school marks was not collected.

When such estimates are disaggregated by graduation cohort (see Table 4, panel A), we find a strong time gradient, whereby the gap is about twice as large at the beginning of the 1990s as it is in 2009. The estimates in panel B, where we do not control for high school marks (and therefore the 1989 cohort also contributes to the analysis) show an even stronger gradient. Although the gap at the start of the sample period is almost 0.1 points in favor of men, in 2009 this is $70 \%$ smaller. Comparing the results in panels A and B suggests that accounting for high school marks accentuates the gender difference in terms of graduation marks from 2001 onwards. This is in line with the significant differences in terms of high school marks seen in Table 2(iii) for these cohorts, and the strong link between high school grades and graduation marks.

High marks. By looking at linear mean regressions we cannot detect nonlinearities. With the second exercise, therefore, we examine whether there are gender differences at the top of the final grade distribution. This allows us to see if there are different effects of gender among high achievers. Using the same specifications employed for the mean graduation marks 
Table 4

Gender Differences in university graduation marks, by cohort and different subsamples.

\begin{tabular}{|c|c|c|c|c|c|c|c|}
\hline & All & 1989 & 1993 & 1997 & 2001 & 2005 & 2009 \\
\hline \multicolumn{8}{|c|}{ A. Graduation mark, controlling for final secondary school grade } \\
\hline \multirow[t]{3}{*}{ Female } & 0.063 & & 0.106 & 0.043 & 0.089 & 0.057 & 0.055 \\
\hline & $(0.006)^{* * *}$ & & $(0.013)^{* * *}$ & $(0.014)^{* *}$ & $(0.014)^{* * *}$ & $(0.012)^{* * *}$ & $(0.014)^{* * *}$ \\
\hline & 42,651 & & 9494 & 8114 & 7048 & 9963 & 8032 \\
\hline \multicolumn{8}{|c|}{ B. Graduation mark (as in A, but not controlling for final secondary school grade) } \\
\hline \multirow[t]{3}{*}{ Female } & 0.055 & 0.094 & 0.104 & 0.043 & 0.065 & 0.030 & 0.031 \\
\hline & $(0.006)^{* * *}$ & $(0.014)^{* * *}$ & $(0.014)^{* * *}$ & $(0.014)^{* *}$ & $(0.015)^{* * *}$ & $(0.012)^{* *}$ & $(0.015)^{* *}$ \\
\hline & 54,108 & 10,767 & 9734 & 8283 & 7150 & 10,078 & 8096 \\
\hline \multicolumn{8}{|c|}{ C. Probability of high graduation mark, controlling for final secondary school grade } \\
\hline \multirow[t]{3}{*}{ Female } & -0.040 & & -0.052 & -0.041 & -0.043 & -0.037 & -0.040 \\
\hline & $(0.005)^{* * *}$ & & $(0.009)^{* * *}$ & $(0.010)^{* * *}$ & $(0.012)^{* * *}$ & $(0.010)^{* * *}$ & $(0.012)^{* * *}$ \\
\hline & 42,651 & & 9494 & 8114 & 7048 & 9963 & 8032 \\
\hline \multicolumn{8}{|c|}{ D. Probability of High Graduation Mark (as C, but not controlling for final secondary school grade) } \\
\hline \multirow[t]{3}{*}{ Female } & -0.035 & -0.044 & -0.051 & -0.040 & -0.029 & -0.019 & -0.026 \\
\hline & $(0.004)^{* * *}$ & $(0.008)^{* * *}$ & $(0.009)^{* * *}$ & $(0.011)^{* * *}$ & $(0.012)^{* *}$ & $(0.010)^{*}$ & $(0.012)^{* *}$ \\
\hline & 54,108 & 10,767 & 9734 & 8283 & 7150 & 10,078 & 8096 \\
\hline
\end{tabular}

Note: Dependent variable is final university grade. Grades are in reverse scale, so that negative coefficient means women have a better final university mark than their male counterparts. Marks are on a scale from 1.0 (best mark) to 4.0 (worst passing mark). 'High graduation mark' refers to a mark of 1.5 or less. Controls in panels A and C are as indicated in column (e) in the Table 3. Controls in panel B and D exclude high school mark but are otherwise identical. In 1989, information on high-school marks was not collected.

regressions before, we estimate linear probability models in which the dependent variable takes value one if an individual obtains a graduation marks of 1.5 or better (i.e., a mark between 1 and 1.5), and zero otherwise.

The results from this analysis are reported in panels $C$ and D of Table 4, where, besides the full set of controls, we investigate the role of secondary school marks as additional control. Irrespective of this inclusion, we find that, across all graduation cohorts, women are 3.5-4 percentage points less likely than men to graduate with top marks, a nontrivial effect that corresponds to about $14 \%-16 \%$ of the sample average probability of obtaining a mark at 1.5 or better.

An important question, therefore, is to understand what happens during the college career of male and female students, given that women start university with an indicator of higher quality (i.e., better secondary school grades). In part, this might be due to a higher dropout rate among men (since equal numbers of men and women enroll and more women graduate), something however we cannot test directly with our data. Dropout rates are substantial: for students starting 2006/07, Heublein et al. (2012) estimate dropout rates for Bachelor students in Germany at 35\% at universities, and 19\% at universities of applied sciences. Comparing across genders, males are found to have a 6-10 percentage points higher dropout rate (at universities, 38\% for males versus 32\% for females; at universities of applied sciences, $23 \%$ for males versus $13 \%$ for females). If academically weaker men abandon their university studies (and do so more than women), each cohort of graduates could be composed of academically stronger men. This in turn may be reflected in their performance in the labor market, which we will analyze in the next section. Of course, there could be other explanations, for instance, universities might have academic curricula that fit men's abilities better than women's, or build men's skills more efficiently than women's. These questions are an interesting issue for future work.

Heterogeneity by field of study. In the last exercise, we look at differences in graduation marks in the four subject categories we already analyzed above (economics/business, STEM, humanities, and medical sciences). These have different gender compositions (e.g., humanities are female dominated and STEM subjects are male dominated) and have gone through major changes in terms of gender representation in the last two decades, as shown in Figs. 2 and 3.

Table 5 reports the gender gap estimates by cohort, using the same specification as that shown in panel A of Table 4, i.e., including secondary school marks in all regressions.

There is large effect heterogeneity across degree subjects. Male graduates in STEM subjects and humanities have better marks at graduation than women. The difference over all cohorts is $0.13-0.18$ of a standard deviation in graduation marks and is statistically significant at conventional levels. In the humanities, the gap has become smaller (and statistically insignificant) for the most recent graduation cohort, while in STEM subjects the gap has remained fairly constant over time.

In economics/business, where the fraction of male and female graduates is more similar, the gender differential is substantially smaller, and we cannot detect any significant gap. As documented earlier, medical studies have witnessed a rapid and considerable increase in female graduates. In this field, the gap (favoring men) has grown among graduates in the most recent cohorts, when fewer men obtain medical related degrees. This might indicate an increasing positive selection of men into medical subjects.

We close this section with a summary of its main results. We emphasize six findings. First, since the mid 1990s, roughly equal numbers of men and women enroll in Higher Education programs in Germany. Second, conditional on having completed college, women enter university with better secondary school marks. Third, at the end of their university career, more women than men obtain a degree. Fourth, there is some persistent educational specialization by gender, with substantially more men in STEM subjects and more women in arts and humanities, although this segregation has lessened 
Table 5

Gender differences in university graduation marks, by field of study subgroups.

\begin{tabular}{|c|c|c|c|c|c|c|}
\hline & All & 1993 & 1997 & 2001 & 2005 & 2009 \\
\hline (i) All & $\begin{array}{l}0.063 \\
(0.006)^{* * *} \\
42,651\end{array}$ & $\begin{array}{l}0.106 \\
(0.013)^{* * *} \\
9494\end{array}$ & $\begin{array}{l}0.043 \\
(0.014)^{* *} \\
8114\end{array}$ & $\begin{array}{l}0.089 \\
(0.014)^{* * *} \\
7048\end{array}$ & $\begin{array}{l}0.057 \\
(0.012)^{* * *} \\
9963\end{array}$ & $\begin{array}{l}0.055 \\
(0.014)^{* * *} \\
8032\end{array}$ \\
\hline $\begin{array}{l}\text { (ii) } \\
\text { Economics } \\
\text { /Business }\end{array}$ & $\begin{array}{l}0.022 \\
(0.014) \\
5615 \\
0.093\end{array}$ & $\begin{array}{l}0.041 \\
(0.036) \\
1014 \\
0.126\end{array}$ & $\begin{array}{l}-0.033 \\
(0.032) \\
1163 \\
0.066\end{array}$ & $\begin{array}{l}0.049 \\
(0.039) \\
743 \\
0.103\end{array}$ & $\begin{array}{l}0.021 \\
(0.029) \\
1310 \\
0.096\end{array}$ & $\begin{array}{l}0.041 \\
(0.028) \\
1385 \\
0.093\end{array}$ \\
\hline (iii) STEM & $\begin{array}{l}(0.012)^{* * *} \\
11,826\end{array}$ & $\begin{array}{l}(0.029)^{* * * *} \\
3209\end{array}$ & $\begin{array}{l}(0.030)^{* *} \\
2562\end{array}$ & $\begin{array}{l}(0.027)^{* * * *} \\
2167\end{array}$ & $\begin{array}{l}(0.026)^{* * *} \\
2232\end{array}$ & $\begin{array}{l}(0.032)^{* *} \\
1656\end{array}$ \\
\hline $\begin{array}{l}\text { (iv) } \\
\text { Humanities }\end{array}$ & $\begin{array}{l}0.142 \\
(0.026)^{* * *} \\
3003\end{array}$ & $\begin{array}{l}0.085 \\
(0.070) \\
548\end{array}$ & $\begin{array}{l}0.159 \\
(0.059)^{* *} \\
565\end{array}$ & $\begin{array}{l}0.234 \\
(0.065)^{* * *} \\
495\end{array}$ & $\begin{array}{l}0.186 \\
(0.050)^{* * *} \\
806\end{array}$ & $\begin{array}{l}0.080 \\
(0.068) \\
589\end{array}$ \\
\hline $\begin{array}{l}\text { (v) Medical } \\
\text { studies }\end{array}$ & $\begin{array}{l}0.053 \\
(0.023)^{* *} \\
2563\end{array}$ & $\begin{array}{l}0.003 \\
(0.042) \\
751\end{array}$ & $\begin{array}{l}0.062 \\
(0.058) \\
442\end{array}$ & $\begin{array}{l}-0.007 \\
(0.061) \\
416\end{array}$ & $\begin{array}{l}0.131 \\
(0.054)^{* *} \\
576\end{array}$ & $\begin{array}{l}0.120 \\
(0.067)^{*} \\
378\end{array}$ \\
\hline
\end{tabular}

Note: Dependent variable is final university grade. Grades are in reverse scale, so that negative coefficient means women have a better final university mark than their male counterparts. Marks are on a scale from 1.0 (best mark) to 4.0 (worst passing mark). Baseline specification (i) is the same as Table 4 , panel A. In 1989, information on high-school marks was not collected. Degree subject groups: the group called 'Humanities' includes literature, language, and philosophy, while 'Medical studies' includes medicine, dentistry, and pharmacy.

in recent years. Fifth, female graduates do not outperform male graduates in terms of final exit marks. The difference reveals a better performance among male graduates. This is clearer when we look at the top of the final university grade distribution, whereby men are 3.5 percentage point more likely to obtain top grades than women over the whole sample period. Sixth, gender gaps in graduation marks differ by field of study. When we pool graduation cohorts, we detect larger differentials among graduates in the humanities and STEM subjects. The reversal of relative performance at the end as opposed to the start of the university career is interesting and, to our knowledge, new.

\section{Gender gaps in the labor market}

To assess the extent of gender differentials in the labor market we begin with an analysis of the earnings gap among full-time workers observed 12-18 months after graduation. We will start by looking at differences at the mean, but then also analyze effects across the earnings distribution. We then consider the gender difference in the probability of being in full-time employment and the number of hours worked. Finally, we perform a decomposition analysis of the earnings gap so that we can better gauge the role played by different sets of predictors, especially those that are not normally observed in nationally representative datasets, such as university attended and fields of study.

\subsection{Earnings}

At the mean. Table 6 reports estimates of the gender gap obtained from different sample selections and with or without the inclusion of different sets of correlates. To avoid issues related to choices or constraints which we do not model here, we focus on full-time workers only. The gender gap in full-time earnings over the whole period is 28.7 log points, including only graduation cohort and state dummies (row (i)). This is remarkably close to the figures reported in Machin and Puhani (2003), although those refer to all graduates, and not just recent graduates. The temporal pattern of the gap is only slightly negative, going down from $34 \log$ points in 1989 to only 24 in 2009. This gap may in part reflect a differential propensity by gender to enter into different types of paid professional training (e.g., lawyers, medical doctors, and teachers) or to start a salaried doctoral program of study. Although paid, both training programs and Ph.D. studies are likely to be paid below market wages. Excluding individuals in training or Ph.D. programs leads to the estimates shown in the second row (row (ii)). About 30 per cent of the sample are dropped, and the gender gap becomes one-third smaller, but without a clear time trend. Selecting the sample further (i.e., requiring the availability of secondary school marks data, and thus dropping the 1989 cohort) leads to virtually identical gender gap estimates (row (iii)).

The inclusion of a large set of controls (i.e., personal characteristics, family background variables, graduation university score, university fixed effects, and field of study fixed effects) reduces, but does not eliminate, the gender pay gap. When all individuals are included (row (iv)), this goes down to $7.8 \mathrm{log}$ points for all cohorts pooled together, a reduction of more than $70 \%$ in comparison to the estimates shown in the first row. We also see a more pronounced reduction over time, with the gap almost halving from $10.1 \mathrm{log}$ points in 1989 to 5.6 log points in 2009. The inclusion of controls in the sample in which men and women in professional training or doctoral programs are excluded (row (v)) leads also to a smaller gender gap than in the case without controls in row (ii). The reduction is about 55\%-60\%, with a resulting gender gap of 8.4 log 
Table 6

Gender earnings gap, by cohort and different subsamples.

\begin{tabular}{|c|c|c|c|c|c|c|c|c|}
\hline & Sample & All cohorts & 1989 & 1993 & 1997 & 2001 & 2005 & 2009 \\
\hline \multicolumn{9}{|c|}{ A. Raw gap } \\
\hline (i) & $\begin{array}{l}\text { All full-time workers (including } \\
\text { graduates in practical training or } \\
\text { enrolled for Ph.D.) }\end{array}$ & $\begin{array}{l}-0.287 \\
(0.006)^{* * *} \\
28,286\end{array}$ & $\begin{array}{l}-0.340 \\
(0.015)^{* * *} \\
4973\end{array}$ & $\begin{array}{l}-0.249 \\
(0.012)^{* * *} \\
5260\end{array}$ & $\begin{array}{l}-0.294 \\
(0.012)^{* * *} \\
5038\end{array}$ & $\begin{array}{l}-0.260 \\
(0.015)^{* * *} \\
4529\end{array}$ & $\begin{array}{l}-0.311 \\
(0.014)^{* * *} \\
5065\end{array}$ & $\begin{array}{l}-0.239 \\
(0.015)^{* * *} \\
3421\end{array}$ \\
\hline (ii) & $\begin{array}{l}\text { Excluding graduates in practical } \\
\text { training or enrolled for Ph.D. }\end{array}$ & $\begin{array}{l}-0.191 \\
(0.005)^{* * *} \\
19,418\end{array}$ & $\begin{array}{l}-0.248 \\
(0.012)^{* * *} \\
3164\end{array}$ & $\begin{array}{l}-0.157 \\
(0.011)^{* * *} \\
3468\end{array}$ & $\begin{array}{l}-0.172 \\
(0.012)^{* * *} \\
3469\end{array}$ & $\begin{array}{l}-0.180 \\
(0.013)^{* * *} \\
3180\end{array}$ & $\begin{array}{l}-0.223 \\
(0.014)^{* * *} \\
3692\end{array}$ & $\begin{array}{l}-0.158 \\
(0.014)^{* * *} \\
2445\end{array}$ \\
\hline (iii) & $\begin{array}{l}\text { As (ii), requiring presence of final } \\
\text { secondary school mark }\end{array}$ & $\begin{array}{l}-0.183 \\
(0.006)^{* * *} \\
15,982\end{array}$ & & $\begin{array}{l}-0.159 \\
(0.011)^{* * *} \\
3351\end{array}$ & $\begin{array}{l}-0.174 \\
(0.012)^{* * *} \\
3402\end{array}$ & $\begin{array}{l}-0.180 \\
(0.013)^{* * *} \\
3158\end{array}$ & $\begin{array}{l}-0.224 \\
(0.014)^{* * *} \\
3648\end{array}$ & $\begin{array}{l}-0.160 \\
(0.015)^{* * *} \\
2423\end{array}$ \\
\hline \multicolumn{9}{|c|}{ B. Controlling for family background, field of study FE, university FE } \\
\hline (iv) & $\begin{array}{l}\text { All full-time workers (including } \\
\text { graduates in practical training or } \\
\text { enrolled for Ph.D.) }\end{array}$ & $\begin{array}{l}-0.078 \\
(0.005)^{* * *} \\
28,286\end{array}$ & $\begin{array}{l}-0.101 \\
(0.013)^{* * *} \\
4973\end{array}$ & $\begin{array}{l}-0.077 \\
(0.010)^{* * *} \\
5260\end{array}$ & $\begin{array}{l}-0.070 \\
(0.011)^{* * *} \\
5038\end{array}$ & $\begin{array}{l}-0.061 \\
(0.014)^{* * *} \\
4529\end{array}$ & $\begin{array}{l}-0.093 \\
(0.013)^{* * *} \\
5065\end{array}$ & $\begin{array}{l}-0.056 \\
(0.014)^{* * *} \\
3421\end{array}$ \\
\hline (v) & $\begin{array}{l}\text { Excluding graduates in practical } \\
\text { training or enrolled for Ph.D. }\end{array}$ & $\begin{array}{l}-0.084 \\
(0.006)^{* * *} \\
19,418\end{array}$ & $\begin{array}{l}-0.100 \\
(0.013)^{* * *} \\
3164\end{array}$ & $\begin{array}{l}-0.095 \\
(0.013)^{* * *} \\
3468\end{array}$ & $\begin{array}{l}-0.083 \\
(0.013)^{* * *} \\
3469\end{array}$ & $\begin{array}{l}-0.078 \\
(0.015)^{* * *} \\
3180\end{array}$ & $\begin{array}{l}-0.091 \\
(0.015)^{* * *} \\
3692\end{array}$ & $\begin{array}{l}-0.050 \\
(0.016)^{* *} \\
2445\end{array}$ \\
\hline \multicolumn{9}{|c|}{ C. Also controlling for final secondary school mark (excludes 1989) } \\
\hline (vi) & $\begin{array}{l}\text { Excl. grad. in practical training or } \\
\text { enrolled for Ph.D., excluding } 1989\end{array}$ & $\begin{array}{l}-0.083 \\
(0.006)^{* * *} \\
15,982\end{array}$ & & $\begin{array}{l}-0.098 \\
(0.013)^{* * *} \\
3351\end{array}$ & $\begin{array}{l}-0.085 \\
(0.013)^{* * *} \\
3402\end{array}$ & $\begin{array}{l}-0.078 \\
(0.015)^{* * *} \\
3158\end{array}$ & $\begin{array}{l}-0.097 \\
(0.015)^{* * *} \\
3648\end{array}$ & $\begin{array}{l}-0.056 \\
(0.016)^{* * *} \\
2423\end{array}$ \\
\hline (vii) & $\begin{array}{l}\text { All full-time workers (including } \\
\text { graduates in practical training or } \\
\text { enrolled for Ph.D.), excluding } 1989\end{array}$ & $\begin{array}{l}-0.074 \\
(0.006)^{* * *} \\
22,981\end{array}$ & & $\begin{array}{l}-0.078 \\
(0.011)^{* * *} \\
5121\end{array}$ & $\begin{array}{l}-0.071 \\
(0.012)^{* * *} \\
4956\end{array}$ & $\begin{array}{l}-0.060 \\
(0.014)^{* * *} \\
4495\end{array}$ & $\begin{array}{l}-0.097 \\
(0.013)^{* * *} \\
5015\end{array}$ & $\begin{array}{l}-0.061 \\
(0.014)^{* * *} \\
3394\end{array}$ \\
\hline \multicolumn{9}{|c|}{ D. Also controlling for hours worked (only 2009) } \\
\hline (viii) & $\begin{array}{l}\text { Excl. grad. in practical training or } \\
\text { enrolled for Ph.D., } 2009 \text { only }\end{array}$ & $\begin{array}{l}-0.055 \\
(0.016)^{* * *} \\
2423\end{array}$ & & & & & & $\begin{array}{l}-0.055 \\
(0.016)^{* * *} \\
2423\end{array}$ \\
\hline
\end{tabular}

Notes: Dependent variable is log monthly earnings, measured in 2001 Euro. Sample restricted to full-time workers. Table reports coefficient on female, and standard errors in parentheses. ( $N$ denotes the number of individuals.) Panel A controls for cohort FE and region FE. Panel B additionally controls for family background, field of study FE, and university FE. Panel C additionally controls for final secondary school grade (not collected in 1989). Panel D additionally controls for the number of hours worked (among the full-time workers), restricted to the 2009 cohort. Rows (i), (ii), (iii) differ in the sample definition. Row (i) includes all graduates in full-time employment (including those in practical training following their degree (e.g. teachers or lawyers), or those enrolled for a Ph.D). Rows (ii) and (iii) exclude these individuals (similarly (v) and (vi)). See text for details.

points (across all cohorts). Once we account for covariates therefore we obtain similar estimates of the gap irrespective of whether we exclude or include the subpopulation of individuals in professional training or Ph.D. programs.

Controlling for secondary school (Abitur) marks does not affect the estimated gap regardless of the selection on training (rows (vi) and (vii)), nor does the inclusion of weekly hours worked (row (viii)), although this last addition can only be assessed for the 2009 cohort (because detailed information on hours of work among full-time workers was collected only for the 2009 cohort).

Previous research has emphasized the importance of the relationship between pay and hours, with nonlinearities indicating a higher career cost of family (Goldin and Katz, 2016). If there is linearity, a worker who works, say, 80 hours a week will be paid twice as much as another worker who works 40 hours. Female full-timers may earn less than their male counterparts, but this might be entirely driven by the fewer hours they work; and women might deliberately choose to work fewer hours because they wish to have greater flexibility and balance job and family responsibilities. The results in Table 6 suggest that hours differences do not play a major role in driving gender earnings gaps in our context, since including hours worked in the analysis does not eliminate the pay differential between men and women. ${ }^{19}$

The estimates in Table 6 are remarkably close to those reported by Bertrand et al. (2010) for the Chicago MBAs at 1-3 years since MBA receipt. There are two striking features in this similarity. The first is that our estimates refer to a different country, with a different school system, and different labor market institutions, employment protection laws, and maternity leave regulations. The second is that they emerge across all university graduates in Germany, not just those in the corporate and financial sectors in which MBA holders are typically employed and where it is known that women are not getting ahead fast enough (e.g., Bertrand and Hallock, 2001; Philippon and Reshef, 2012; Wolfers, 2006).

A formal decomposition of the earnings gap using gender differences in means of the explanatory variables and the coefficients from the specification in line ( $v$ ) of Table 6 shows that the single most important contribution to the mean level of the gender earnings gap across all graduation cohorts is given by field of study (see Table 7). This proximate factor alone can account for $9.4 \mathrm{log}$ points of the explained difference between male and female earnings (or $83 \%$ of the $11.3 \mathrm{log}$ point explained average gap). The same occurs when we examine each graduation cohort separately. Similar results also emerge when we analyze the larger sample that does not exclude graduates in professional training and Ph.D. programs

\footnotetext{
19 See Section 4.2 for estimates of gender differences in hours worked.
} 
Table 7

Decomposition of the Gender earnings gap, by cohort.

\begin{tabular}{|c|c|c|c|c|c|c|c|}
\hline & All & 1989 & 1993 & 1997 & 2001 & 2005 & 2009 \\
\hline Observed gender wage gap & 0.197 & 0.245 & 0.151 & 0.186 & 0.195 & 0.235 & 0.164 \\
\hline Explained & 0.113 & 0.145 & 0.056 & 0.103 & 0.117 & 0.143 & 0.114 \\
\hline \multicolumn{8}{|l|}{ Part explained by: } \\
\hline Cohort FE & -0.001 & & & & & & \\
\hline Region FE & 0.009 & -0.001 & -0.004 & 0.011 & 0.012 & 0.009 & 0.001 \\
\hline Personal characteristics & 0.012 & 0.012 & 0.009 & 0.007 & 0.008 & 0.008 & 0.013 \\
\hline Family background & -0.003 & -0.003 & -0.006 & -0.003 & 0.001 & -0.001 & 0.001 \\
\hline Graduation mark & -0.004 & -0.001 & -0.002 & 0.000 & -0.002 & -0.001 & -0.001 \\
\hline Field of study & 0.094 & 0.147 & 0.061 & 0.080 & 0.094 & 0.115 & 0.108 \\
\hline University FE & 0.006 & -0.008 & -0.003 & 0.007 & 0.004 & 0.013 & -0.007 \\
\hline Unexplained & 0.084 & 0.100 & 0.095 & 0.083 & 0.078 & 0.091 & 0.050 \\
\hline$N$ & 19,418 & 3164 & 3468 & 3469 & 3180 & 3692 & 2445 \\
\hline
\end{tabular}

Notes: Table reports decomposition results, the dependent variable is log monthly earnings for full-time workers. The sample is as in Table 6, panel A, row (ii). See text for details.

(see Appendix Table A.1). Leuze and Strauß find that descriptively those subjects with high share of females tend to be associated with lower labor market returns. These findings are consistent with the evidence put forward by Machin and Puhani (2003) for Germany and the UK, even though their study focuses on all graduates and not just those who are observed one year to 18 months since graduation. They are also consistent with recent evidence that shows that different fields of study have substantially different labor market payoffs, even after accounting for individuals characteristics and awarding institution (e.g., Kirkeboen et al., 2016).

At Different Quantiles. One well established result for Sweden is that, although male and female wages are close to equal at the bottom of the wage distribution, they become extremely unequal at the top of the distribution (Albrecht et al., 2003), where presumably there is a greater concentration of college graduates. Similar evidence of greater gender differences at the top is also found among recent cohorts of full-time American workers (Blau and Kahn, 2017) and English graduates (see Britton et al., 2016). For Germany, Gallego-Granados and Geyer (2015) find that the gender wage gap decreases for higher quantiles, while Antonczyk et al. (2010) find a U-shaped gender wage gap. ${ }^{20}$ In what follows, we explore the gender earnings gap at different percentiles of the distribution for university graduates.

Fig. 4 shows the results. Regarding the raw gender difference, we observe a larger gender pay gap among lower paid graduates than among their better paid counterparts. To investigate what share of the raw gap can be explained by the covariates, we use the decomposition method described in Chernozhukov et al. (2013). The results are reported in Appendix Table A.2. It is striking that once our rich set of covariates is controlled for, the gender wage gap is very similar across the quantiles, at around 7\% (see Table A.2). As a result, the variables we use in our models can explain substantially more at the bottom of the distribution than at the top. We find that our covariates explain $65 \%-75 \%$ of the gap in the bottom three deciles, but only $30 \%-40 \%$ in the top two deciles. Interestingly, further results (not shown for space constraints) show that this pattern is essentially driven by the role of major choice, this is in line with the results in Table 7.

\subsection{Full-time employment and hours}

Previous research has emphasized that a major reason gender differences in earnings are observed is due to differences in job experience and hours, and a large part of such differences comes from job interruptions, with most job interruptions being due to children (Angelov et al., 2016; Bertrand et al., 2010; Bütikofer et al., 2017; Goldin and Katz, 2016; Goldin and Mitchell, 2017; Juhn and McCue, 2017; Sasser, 2005; Wood et al., 1993). By looking at gaps occurring 1-1.5 years out since graduation, we are likely to mitigate most of these channels which possibly emerge only after a longer time span. Here we explore the role played by the differential selection into full-time employment and by differences in weekly hours of work.

Table 8 shows the results of this analysis. In the first two columns we report the estimates from linear probability models in which the dependent variable equals 1 if individuals are in full-time employment, and 0 part-time. Even soon after graduation, female graduates show a significantly lower propensity to be employed in a full-time job. When we consider all cohorts together, the (raw) employment gap is 9 percentage points (column (a), where we only control for cohort dummies). This gap has varied between 7 and 13 percentage points between 1989 and 2005, while only among graduates from the 2009 cohort do we observe a substantial reduction in the gap to less than 6 percentage points.

When we include the whole set of (individual, family background, pre-university and university) controls, the gender employment differential becomes considerably smaller, less than 2.5 percentage points among graduates across all cohorts, but still statistically significant (column (b)). For the most recent cohort, however, we find a reversal in the gap, with female graduates experiencing a greater likelihood of being employed full time by 1.1 percentage points than their male

\footnotetext{
20 International comparisons can be found in Arulampalam et al. (2007) and Christofides et al. (2013).
} 


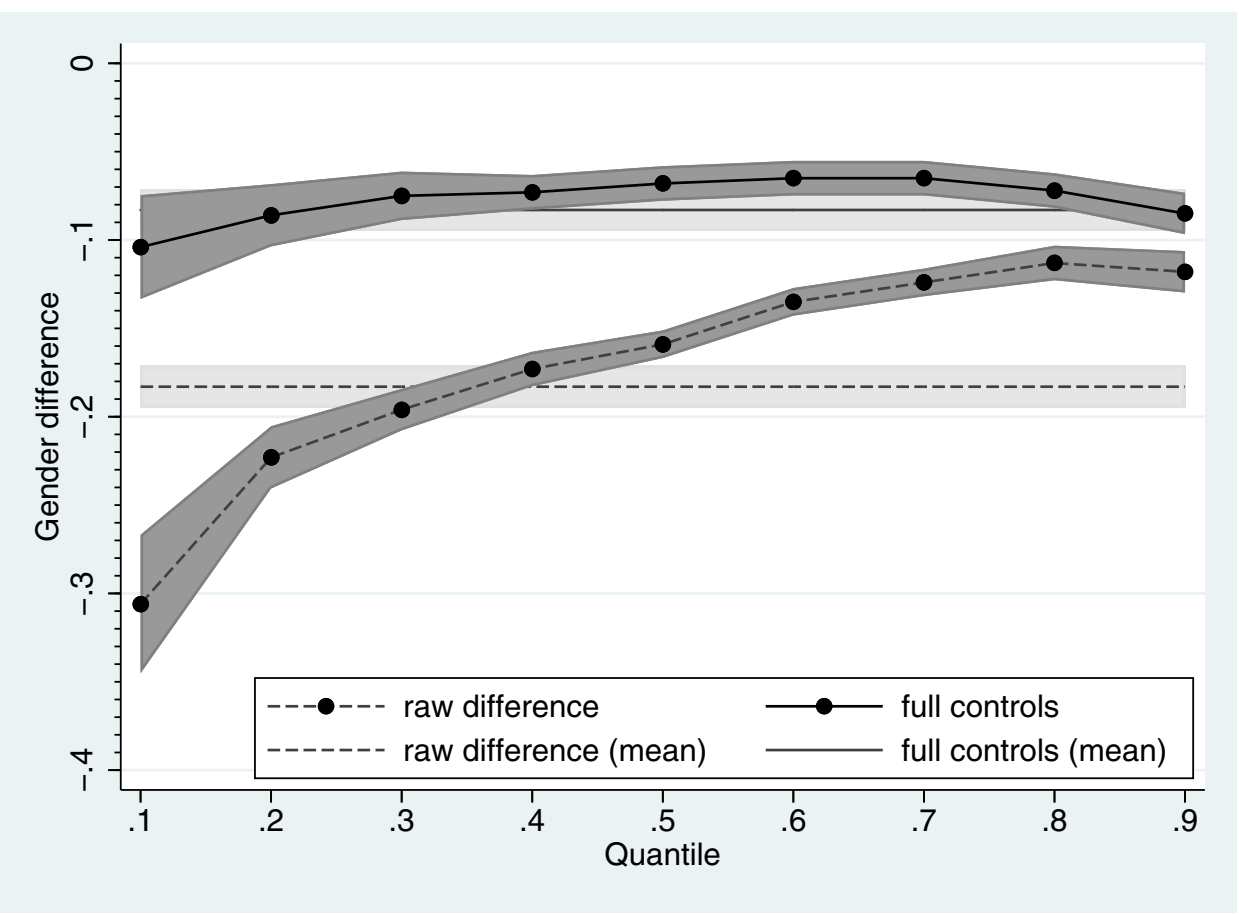

Fig. 4. Gender difference in log full time monthly earnings across the distribution. Note: Figure shows coefficients and confidence intervals for the female indicator variable obtained from quantile regression models for quantiles $0.1,0.2, \ldots, 0.9$ (shown with black dots and dark gray), as well as benchmark OLS estimates (shown without dots in light gray). Sample excludes the 1989 cohort. (In 1989, earnings are surveyed in brackets, and the 1989 wave of data does not contain final secondary school grades.) Sample and specification as in Table 6, panel C, row (vi). $N$ (number of individuals) $=15,982$. See text for details.

Table 8

Fulltime employment and hours, by cohort and specification.

\begin{tabular}{|c|c|c|c|c|c|c|}
\hline & \multirow{2}{*}{\multicolumn{2}{|c|}{$\begin{array}{l}\text { Full-time } \\
\text { employment } \\
\text { (Cohorts 89, 93, 97, } \\
01,05,09 \text { ) }\end{array}$}} & \multirow{2}{*}{\multicolumn{2}{|c|}{$\begin{array}{l}\text { Ever employed } \\
\text { since graduation } \\
\text { (Cohorts 2001, 2005, } \\
\text { 2009) }\end{array}$}} & \multicolumn{2}{|c|}{$\begin{array}{l}\text { Hours } \\
\text { (Cohort 2009) } \\
\end{array}$} \\
\hline & & & & & & \\
\hline & $\begin{array}{l}\text { (a) } \\
\text { Cohort FE }\end{array}$ & $\begin{array}{l}\text { (b) } \\
\text { + age, family } \\
\text { background, } \\
\text { final grade, } \\
\text { field } \mathrm{FE} \text {, uni FE. }\end{array}$ & $\begin{array}{l}\text { (c) } \\
\text { Cohort FE }\end{array}$ & $\begin{array}{l}\text { (d) } \\
\text { + age, family } \\
\text { background, final grade, } \\
\text { field } \mathrm{FE} \text {, uni } \mathrm{FE} \text {. }\end{array}$ & $\begin{array}{l}\text { (e) } \\
\text { Cohort FE, } \\
\text { region FE }\end{array}$ & $\begin{array}{l}\text { (f) } \\
\text { + age, family } \\
\text { background, final grade, } \\
\text { field of study FE, } \\
\text { university FE }\end{array}$ \\
\hline All & $\begin{array}{l}-0.090 \\
(0.004)^{* * * *} \\
44,544\end{array}$ & $\begin{array}{l}-0.024 \\
(0.004)^{* * *} \\
44,544\end{array}$ & $\begin{array}{l}-0.005 \\
(0.004) \\
25,321\end{array}$ & $\begin{array}{l}0.017 \\
(0.005)^{* * *} \\
25,321\end{array}$ & $\begin{array}{l}-0.21 \\
(0.106)^{* *} \\
3673\end{array}$ & $\begin{array}{l}-0.386 \\
(0.128)^{* *} \\
3673\end{array}$ \\
\hline 1989 & $\begin{array}{l}-0.106 \\
(0.008)^{* * * *} \\
9200\end{array}$ & $\begin{array}{l}-0.032 \\
(0.009)^{* * * *} \\
9200\end{array}$ & & & & \\
\hline 1993 & $\begin{array}{l}-0.065 \\
(0.010)^{* * *} \\
7911\end{array}$ & $\begin{array}{l}-0.025 \\
(0.011)^{* *} \\
7911\end{array}$ & & & & \\
\hline 1997 & $\begin{array}{l}-0.102 \\
(0.010)^{* * *} \\
7080\end{array}$ & $\begin{array}{l}-0.032 \\
(0.011)^{* *} \\
7080\end{array}$ & & & & \\
\hline 2001 & $\begin{array}{l}-0.066 \\
(0.010)^{* * *} \\
6414\end{array}$ & $\begin{array}{l}-0.034 \\
(0.011)^{* *} \\
6414\end{array}$ & $\begin{array}{l}-0.015 \\
(0.005)^{* *} \\
7150\end{array}$ & $\begin{array}{l}-0.012 \\
(0.006)^{* *} \\
7150\end{array}$ & & \\
\hline 2005 & $\begin{array}{l}-0.127 \\
(0.010)^{* * *} \\
8035\end{array}$ & $\begin{array}{l}-0.054 \\
(0.011)^{* * * *} \\
8035\end{array}$ & $\begin{array}{l}-0.022 \\
(0.007)^{* *} \\
10,075\end{array}$ & $\begin{array}{l}0.009 \\
-0.008 \\
10,075\end{array}$ & & \\
\hline 2009 & $\begin{array}{l}-0.058 \\
(0.013)^{* * * *} \\
5904\end{array}$ & $\begin{array}{l}0.011 \\
-0.014 \\
5904\end{array}$ & $\begin{array}{l}0.025 \\
(0.009)^{* *} \\
8096\end{array}$ & $\begin{array}{l}0.041 \\
(0.010)^{* * * *} \\
8096\end{array}$ & $\begin{array}{l}-0.21 \\
(0.106)^{* *} \\
3673\end{array}$ & $\begin{array}{l}-0.386 \\
(0.128)^{* *} \\
3673\end{array}$ \\
\hline
\end{tabular}

Note: Columns (a) and (b): dependent variable is full-employment indicator, taking value 1 if individual is in full-time employment, and 0 for part-time work. Columns (c) and (d): dependent variable is indicator for ever employed since graduation (including temporary jobs, teacher training positions, employment as Ph.D. student, freelance work). Panels (e)-(f): dependent variable is hours worked per week, among full-time workers (only available in 2009 cohort). Controls are indicated at the top of the table. See text for details. 
counterparts, although this gap is not statistically significantly different from zero. Standard decomposition analysis shows that field of study plays again a major role in explaining the gap by gender (not reported for the sake of brevity).

In columns (c) and (d), we take advantage of additional detailed information on forms of employment other than fulland part-time jobs, such as employment in temporary jobs and freelance work. This information is only available from the 2001 cohort onwards. The results show that, in the most recent cohort, women are 3-4 percentage points more likely to be ever employed than their male counterparts.

The last two columns of Table 8 (columns (e) and (f)) display the estimates on the gender differences in hours worked. These refer to the 2009 cohort only because, as mentioned before, information on hours of work for full-time employees was collected in the 2009 round but not in the earlier waves. Every week women work about 0.2 fewer hours than men. When all controls are included, the gap grows to about 0.39 hours a week. This difference of around 25 min of work per week is statistically significant and accounts for about $12 \%$ of a standard deviation in hours worked. The difference cannot account for more than $15 \%$ of the $6 \log$ point difference between male and female pay found for the 2009 cohort (see Table 6 , row (viii)). Thus, hours of work are important in this context, but are unlikely to be the whole story among full-timers.

In sum, 12-18 months out of university, gender gaps on the intensive margin are quantitatively small and appear to play only a minor role in explaining the observed gender pay gap. Gender gaps on the extensive margin instead are more pronounced, and field of study turns out to be a key proximate factor in determining such differentials. To understand more about the role played by degree categories, we next analyze the extent of full-time gender earnings gaps across different fields of study.

\subsection{Heterogeneity by field of study}

We look again at the four different degree subjects we have already analyzed before (Table 9). Panel A shows the estimates obtained on the sample that excludes individuals in training and Ph.D. programs, whereas panel B includes such individuals. In interpreting the estimates one needs to keep in mind that different subject fields have different propensities for further training, as seen from the difference in sample sizes between panels A and B in Table 9.

The gap between male and female economics/business graduates is insensitive to sample selection and type of specification. Just controlling for cohort and regional dummies results in a gender gap of about $10 \log$ points (column (a)). After all controls are accounted for (specification (e)), the gap remains essentially unchanged and always highly statistically significant.

More variation is instead observed for the other fields. For example, when we only condition on time and regional dummies (specification (a)), the full-time gender earnings gap is $30 \log$ points among STEM graduates if we include individuals involved in training/Ph.D. programs (panel B), but it reduces to $13 \log$ points if we exclude them (panel A).

In the case of medical studies, we find a significant pay gap of about $9 \log$ points in panel A. Including individuals in training and internship programs leads a much larger sample (panel B), in which however we cannot detect any significant pay differential by gender. Similar patterns emerge in the case of humanities, albeit with different values of the estimated gender gaps.

Overall, in Panel A the point estimates are quite similar across subjects (column (e)), even though the estimate for humanities is not statistically significant. In Panel B, however, there is a striking difference between Economics/Business and STEM on the one hand, with significant gender gaps close to $12 \mathrm{log}$ points, and Humanities and Medical studies on the other hand, with an insignificant gender gap of around 2 log points. Given a large fraction of graduates in the latter fields are involved in some sort of further training, the next step it to see what happens to their labor incomes after its completion. This is another area to be explored by future research.

\subsection{Public versus private sector}

Recent work by Mas and Pallais (2017) and Wiswall and Zafar (2018) suggests that there are significant differences in male versus female valuation of non-wage benefits, and job stability and work flexibility in particular. We investigate this point by comparing the gender-specific probability of entering the public sector. Clearly there are many potential differences between public and private sector jobs. Nonetheless, the additional job security and the flexibility in terms of work-time (including the ability to adjust between full-time and part-time as family circumstances change) is a potentially important aspect in this context. Table A.3 shows the results, where indeed we find a striking difference between gender. Across all subjects, females are 4 percentage points more likely to enter the public sector than males, which is a substantial difference given the baseline rate of about 13\%. In particular, when we look at STEM subjects, females are 8 percentage points more likely to work in the public sector, compared to an overall mean of less than 10 per cent. In our data, monthly earnings of public sector workers are significantly lower (controlling for field of study). ${ }^{21}$ This suggests that these tradeoffs maybe very relevant in the population we are studying. Occupational and sectoral choice are therefore important areas for future research.

\footnotetext{
${ }^{21}$ Results not shown for space constraints. Of course, it is important to keep in mind that other differences such as differences in pensions are not reflected in this estimate.
} 
Table 9

Gender earnings gap, by field of study and specification.

\begin{tabular}{|c|c|c|c|c|c|}
\hline & $\begin{array}{l}\text { Cohort and } \\
\text { region FE } \\
\text { (a) }\end{array}$ & $\begin{array}{l}+ \text { age, family } \\
\text { background } \\
\text { (b) }\end{array}$ & $\begin{array}{l}+ \text { final } \\
\text { secondary } \\
\text { school grade } \\
\text { (c) }\end{array}$ & $\begin{array}{l}\text { + field of } \\
\text { study FE } \\
\text { (d) }\end{array}$ & $\begin{array}{l}+ \text { university } \\
\mathrm{FE} \\
\text { (e) }\end{array}$ \\
\hline \multicolumn{6}{|c|}{ A. Excluding graduates in training and Ph.D. studies (full-time employed only) } \\
\hline (i) All & $\begin{array}{l}-0.191 \\
(0.005)^{* * *} \\
19,418\end{array}$ & $\begin{array}{l}-0.185 \\
(0.005)^{* * *} \\
19,418\end{array}$ & $\begin{array}{l}-0.185 \\
(0.005)^{* * *} \\
19,418\end{array}$ & $\begin{array}{l}-0.086 \\
(0.006)^{* * *} \\
19,418\end{array}$ & $\begin{array}{l}-0.084 \\
(0.006)^{* * *} \\
19,418\end{array}$ \\
\hline $\begin{array}{l}\text { (ii) } \\
\text { Economics } \\
\text { / Business }\end{array}$ & $\begin{array}{l}-0.103 \\
(0.010)^{* * *} \\
3835\end{array}$ & $\begin{array}{l}-0.100 \\
(0.010)^{* * *} \\
3835\end{array}$ & $\begin{array}{l}-0.108 \\
(0.010)^{* * *} \\
3835\end{array}$ & $\begin{array}{l}-0.108 \\
(0.010)^{* * *} \\
3835\end{array}$ & $\begin{array}{l}-0.101 \\
(0.010)^{* * * *} \\
3835\end{array}$ \\
\hline (iii) STEM & $\begin{array}{l}-0.134 \\
(0.009)^{* * *} \\
6825\end{array}$ & $\begin{array}{l}-0.125 \\
(0.009)^{* * *} \\
6825\end{array}$ & $\begin{array}{l}-0.123 \\
(0.009)^{* * *} \\
6825\end{array}$ & $\begin{array}{l}-0.095 \\
(0.009)^{* * *} \\
6825\end{array}$ & $\begin{array}{l}-0.092 \\
(0.009)^{* * * *} \\
6825\end{array}$ \\
\hline $\begin{array}{l}\text { (iv) } \\
\text { Humanities }\end{array}$ & $\begin{array}{l}-0.132 \\
(0.059)^{* *} \\
609\end{array}$ & $\begin{array}{l}-0.097 \\
(0.061) \\
609\end{array}$ & $\begin{array}{l}-0.099 \\
(0.061) \\
609\end{array}$ & $\begin{array}{l}-0.095 \\
(0.062) \\
609\end{array}$ & $\begin{array}{l}-0.097 \\
(0.065) \\
609\end{array}$ \\
\hline $\begin{array}{l}\text { (v) } \\
\text { Medical } \\
\text { studies } \\
\text { B. Including }\end{array}$ & $\begin{array}{l}-0.093 \\
(0.027)^{* * *} \\
518 \\
\text { Ph.D. studie }\end{array}$ & $\begin{array}{l}-0.074 \\
(0.028)^{* *} \\
518 \\
\text { employed only }\end{array}$ & $\begin{array}{l}-0.074 \\
(0.028)^{* *} \\
518\end{array}$ & $\begin{array}{l}-0.081 \\
(0.028)^{* *} \\
518\end{array}$ & $\begin{array}{l}-0.080 \\
(0.028)^{* *} \\
518\end{array}$ \\
\hline (i) All & $\begin{array}{l}-0.287 \\
(0.006)^{* * *} \\
28,286\end{array}$ & $\begin{array}{l}-0.266 \\
(0.006)^{* * *} \\
28,286\end{array}$ & $\begin{array}{l}-0.261 \\
(0.006)^{* * *} \\
28,286\end{array}$ & $\begin{array}{l}-0.081 \\
(0.005)^{* * *} \\
28,286\end{array}$ & $\begin{array}{l}-0.078 \\
(0.005)^{* * * *} \\
28,286\end{array}$ \\
\hline $\begin{array}{l}\text { (ii) } \\
\text { Economics } \\
\text { / Business }\end{array}$ & $\begin{array}{l}-0.112 \\
(0.011)^{* * *} \\
4144 \\
-0.300\end{array}$ & $\begin{array}{l}-0.116 \\
(0.011)^{* * *} \\
4144 \\
-0.270\end{array}$ & $\begin{array}{l}-0.122 \\
(0.011)^{* * *} \\
4144 \\
-0.267\end{array}$ & $\begin{array}{l}-0.122 \\
(0.011)^{* * *} \\
4144 \\
-0.128\end{array}$ & $\begin{array}{l}-0.119 \\
(0.011)^{* * *} \\
4144 \\
-0.116\end{array}$ \\
\hline (iii) STEM & $\begin{array}{l}(0.010)^{* * * *} \\
8392\end{array}$ & $\begin{array}{l}(0.010)^{* * *} \\
8392\end{array}$ & $\begin{array}{l}(0.010)^{* * * *} \\
8392\end{array}$ & $\begin{array}{l}(0.010)^{* * * *} \\
8392\end{array}$ & $\begin{array}{l}(0.010)^{* * * *} \\
8392\end{array}$ \\
\hline $\begin{array}{l}\text { (iv) } \\
\text { Humanities }\end{array}$ & $\begin{array}{l}-0.081 \\
(0.028)^{* *} \\
1581\end{array}$ & $\begin{array}{l}-0.012 \\
(0.028) \\
1581\end{array}$ & $\begin{array}{l}-0.007 \\
(0.029) \\
1581\end{array}$ & $\begin{array}{l}-0.009 \\
(0.028) \\
1581\end{array}$ & $\begin{array}{l}-0.018 \\
(0.028) \\
1581\end{array}$ \\
\hline $\begin{array}{l}(\mathrm{v}) \\
\text { Medical } \\
\text { studies }\end{array}$ & $\begin{array}{l}0.014 \\
(0.016) \\
2576\end{array}$ & $\begin{array}{l}-0.014 \\
(0.017) \\
2576\end{array}$ & $\begin{array}{l}-0.016 \\
(0.017) \\
2576\end{array}$ & $\begin{array}{l}-0.021 \\
(0.016) \\
2576\end{array}$ & $\begin{array}{l}-0.024 \\
(0.016) \\
2576\end{array}$ \\
\hline
\end{tabular}

Note: Dependent variable is log monthly earnings for full-time workers. Table reports coefficient (and standard deviation) of the female indicator, as well as number of observations. Additional controls are shown at the top of the table. Panel A: Sample as in Table 6, Panel A(ii). Panel B: Sample as in Table 6, Panel A, row (i). Degree subject groups: the group called 'Humanities' includes literature, language, and philosophy, while 'Medical studies' includes medicine, dentistry, and pharmacy. See text for details.

\section{Discussion and conclusions}

We have examined gender differences in university performance and labor market outcomes among German college graduates. A key aspect of our labor market analysis is that we have focused on the short run, looking at gender gaps soon after graduation, thus limiting the role played by marriage, children, career interruptions, negotiations with employers, and promotions which many have found to put greater constraints on women's careers than men's.

Before 1995, more men entered college than women; but in the following 20 years, the numbers have become roughly equal. More women than men, however, complete their degrees. This is consistent with differential dropout rate by gender which might have consequences on the cohorts of male and female graduates entering the labor market. In terms of quality, female graduates enter college with slightly better high school marks, ${ }^{22}$ but leave university with slightly lower grade levels. This again might reflect a greater dropout rate among men. But it might also reflect other factors (such as men achieving maturity and catching up with women in terms of academic skills, or universities offering programs that are better suited to men's than to women's abilities), which deserve more research in the future.

Immediately following university completion, full-time men earn more than full-time women, even though they have very similar weekly hours of work. Between 12 and 18 months after leaving college, the gender gap in full-time monthly earnings is nearly 20 log points across all graduation cohorts, if individuals in professional training or Ph.D. programs,

\footnotetext{
${ }^{22}$ This result is found conditional on college completion. If it is the case that academically weaker men do not complete their university studies, then the difference in marks between men and women at university entry could be even larger than what we find. 
who are likely to be paid below market wages, are excluded. The single most important proximate factor that explains the sizeable, early gender gap in pay is the field of study at university. There is heterogeneity in the magnitude of the gender pay gap by field of study, with the largest differentials emerging among graduates from economics/business and STEM subjects. Once the full set of controls is taken into account, the remaining wage gap is about $8 \log$ points when we estimate across all available cohorts.

Several channels may be at work here. One could be related to human capital considerations. The importance of field of study in our results indicates the relevance of pre-market choices. These also interact with subsequent market decisions (such as occupational choice) at the very beginning of professional careers (e.g., Canon and Golan, 2017; Liu, 2016). In turn, such choices could be partly driven by gender differences in preferences (e.g., risk aversion), self-confidence, competitiveness, earnings expectations, and valuation of non-wage benefits (e.g., Buser et al., 2014; Fortin, 2008; Mas and Pallais, 2017; Reuben et al., 2017; Wiswall and Zafar, 2015). Joining some (if not all) of these drivers into one coherent analysis would be another important area for future work. Another possible channel is related to statistical discrimination against women, based on employers' difficulty in distinguishing more from less career oriented women (e.g., Gayle and Golan, 2012; Reuben et al., 2014; Thomas, 2018). Also this mechanism deserves more attention in future research.

\section{Appendix}

\begin{tabular}{|c|c|c|c|c|c|c|c|c|c|c|c|c|c|c|c|c|c|c|c|c|}
\hline \multirow{2}{*}{$\begin{array}{c}\text { Graduate } \\
\text { Cohort }\end{array}$} & \multirow[b]{2}{*}{92} & \multirow[b]{2}{*}{93} & \multirow[b]{2}{*}{94} & \multirow[b]{2}{*}{95} & \multirow[b]{2}{*}{96} & \multirow[b]{2}{*}{97} & \multirow[b]{2}{*}{98} & \multirow[b]{2}{*}{99} & \multirow[b]{2}{*}{00} & \multirow[b]{2}{*}{01} & \multirow[b]{2}{*}{02} & \multirow[b]{2}{*}{03} & \multirow[b]{2}{*}{04} & \multirow[b]{2}{*}{05} & \multirow[b]{2}{*}{06} & \multirow[b]{2}{*}{07} & \multirow[b]{2}{*}{08} & \multirow[b]{2}{*}{09} & \multirow[b]{2}{*}{10} & \multirow[b]{2}{*}{11} \\
\hline & & & & & & & & & & & & & & & & & & & & \\
\hline 1993 & 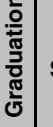 & $\begin{array}{c}1 \text { st } \\
\text { Survey }\end{array}$ & & & & & \multicolumn{2}{|c|}{$\begin{array}{l}\text { Follow-Up } \\
\text { Survey }\end{array}$} & & & & & & & & & & & & \\
\hline 1997 & & & & & & 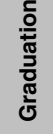 & $\begin{array}{c}\text { 1st } \\
\text { Surv } \\
\text { ey }\end{array}$ & & & & \multicolumn{2}{|c|}{$\begin{array}{l}\text { Follow-Up } \\
\text { Survey }\end{array}$} & & & & & & & & \\
\hline 2001 & & & & & & & & & & 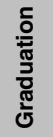 & $\begin{array}{c}\text { 1st } \\
\text { Surv } \\
\text { ey }\end{array}$ & & & & & & & & & \\
\hline 2005 & & & & & & & & & & & & & & 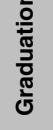 & $\begin{array}{c}\text { 1st } \\
\text { Surv } \\
\text { ey }\end{array}$ & & & & & $\begin{array}{l}\text { v-Up } \\
\text { rey }\end{array}$ \\
\hline
\end{tabular}

Fig. A.1. Design of DZHW graduate panels. Note: The figure shows the timing of the baseline as well as the five-year follow-up surveys of the DZHW graduate panels.

Table A.1

Decomposition of the gender earnings gap, by cohort.

\begin{tabular}{|c|c|c|c|c|c|c|c|}
\hline & All & 1989 & 1993 & 1997 & 2001 & 2005 & 2009 \\
\hline Difference & 0.281 & 0.342 & 0.251 & 0.305 & 0.279 & 0.320 & 0.248 \\
\hline Explained & 0.203 & 0.241 & 0.174 & 0.236 & 0.218 & 0.227 & 0.192 \\
\hline \multicolumn{8}{|l|}{ Part explained by } \\
\hline Cohort FE & -0.009 & & & & & & \\
\hline Region FE & 0.006 & -0.003 & -0.001 & 0.008 & 0.012 & 0.005 & 0.001 \\
\hline Personal characteristics & 0.022 & 0.022 & 0.020 & 0.018 & 0.022 & 0.013 & 0.018 \\
\hline Family background & -0.002 & -0.001 & -0.004 & -0.001 & 0.002 & 0.000 & 0.001 \\
\hline Graduation mark & -0.002 & -0.002 & 0.000 & 0.001 & 0.000 & 0.003 & 0.001 \\
\hline Field of study & 0.167 & 0.195 & 0.140 & 0.179 & 0.158 & 0.176 & 0.138 \\
\hline University FE & 0.021 & 0.029 & 0.019 & 0.031 & 0.025 & 0.030 & 0.033 \\
\hline Unexplained & 0.078 & 0.101 & 0.077 & 0.070 & 0.061 & 0.093 & 0.056 \\
\hline$N$ & 28286 & 4973 & 5260 & 5038 & 4529 & 5065 & 3421 \\
\hline
\end{tabular}

Note: Table reports decomposition results, the dependent variable is log monthly earnings for full-time workers. The sample is as in Table 6, panel A, row (i). See text for details. 
Table A.2

Quantile decomposition of the gender earnings gap, by cohort.

\begin{tabular}{|c|c|c|c|c|}
\hline & Quantile & $\begin{array}{l}\text { Quantile } \\
\text { difference }\end{array}$ & $\begin{array}{l}\text { Effect of } \\
\text { characteristics }\end{array}$ & $\begin{array}{l}\text { Effect of } \\
\text { coefficients }\end{array}$ \\
\hline All & 0.1 & 0.317 & 0.240 & 0.078 \\
\hline \multirow{8}{*}{$(N=19,418)$} & 0.2 & 0.249 & 0.177 & 0.073 \\
\hline & 0.3 & 0.218 & 0.143 & 0.075 \\
\hline & 0.4 & 0.191 & 0.118 & 0.073 \\
\hline & 0.5 & 0.167 & 0.094 & 0.074 \\
\hline & 0.6 & 0.141 & 0.069 & 0.071 \\
\hline & 0.7 & 0.117 & 0.052 & 0.065 \\
\hline & 0.8 & 0.100 & 0.040 & 0.060 \\
\hline & 0.9 & 0.098 & 0.029 & 0.069 \\
\hline 1989 & 0.1 & 0.414 & 0.301 & 0.113 \\
\hline \multirow[t]{8}{*}{$(N=3,164)$} & 0.2 & 0.351 & 0.237 & 0.114 \\
\hline & 0.3 & 0.306 & 0.160 & 0.145 \\
\hline & 0.4 & 0.276 & 0.135 & 0.142 \\
\hline & 0.5 & 0.251 & 0.115 & 0.137 \\
\hline & 0.6 & 0.169 & 0.057 & 0.112 \\
\hline & 0.7 & 0.145 & 0.052 & 0.093 \\
\hline & 0.8 & 0.114 & 0.052 & 0.061 \\
\hline & 0.9 & 0.095 & 0.036 & 0.059 \\
\hline 1993 & 0.1 & 0.181 & 0.130 & 0.051 \\
\hline \multirow{8}{*}{$(N=3468)$} & 0.2 & 0.171 & 0.091 & 0.080 \\
\hline & 0.3 & 0.164 & 0.064 & 0.100 \\
\hline & 0.4 & 0.158 & 0.065 & 0.094 \\
\hline & 0.5 & 0.152 & 0.063 & 0.089 \\
\hline & 0.6 & 0.143 & 0.055 & 0.088 \\
\hline & 0.7 & 0.126 & 0.042 & 0.084 \\
\hline & 0.8 & 0.118 & 0.036 & 0.082 \\
\hline & 0.9 & 0.112 & 0.024 & 0.088 \\
\hline 1997 & 0.1 & 0.352 & 0.174 & 0.178 \\
\hline \multirow[t]{8}{*}{$(N=3469)$} & 0.2 & 0.269 & 0.123 & 0.146 \\
\hline & 0.3 & 0.225 & 0.101 & 0.124 \\
\hline & 0.4 & 0.189 & 0.086 & 0.103 \\
\hline & 0.5 & 0.153 & 0.065 & 0.088 \\
\hline & 0.6 & 0.126 & 0.049 & 0.077 \\
\hline & 0.7 & 0.107 & 0.045 & 0.062 \\
\hline & 0.8 & 0.092 & 0.035 & 0.057 \\
\hline & 0.9 & 0.077 & 0.008 & 0.069 \\
\hline 2001 & 0.1 & 0.272 & 0.277 & -0.005 \\
\hline \multirow[t]{8}{*}{$(N=3,180)$} & 0.2 & 0.240 & 0.185 & 0.055 \\
\hline & 0.3 & 0.219 & 0.145 & 0.073 \\
\hline & 0.4 & 0.206 & 0.120 & 0.085 \\
\hline & 0.5 & 0.186 & 0.092 & 0.094 \\
\hline & 0.6 & 0.171 & 0.070 & 0.101 \\
\hline & 0.7 & 0.151 & 0.045 & 0.105 \\
\hline & 0.8 & 0.136 & 0.023 & 0.113 \\
\hline & 0.9 & 0.133 & -0.009 & 0.142 \\
\hline 2005 & 0.1 & 0.434 & 0.289 & 0.145 \\
\hline \multirow[t]{8}{*}{$(N=3,692)$} & 0.2 & 0.305 & 0.187 & 0.119 \\
\hline & 0.3 & 0.266 & 0.162 & 0.103 \\
\hline & 0.4 & 0.234 & 0.143 & 0.090 \\
\hline & 0.5 & 0.211 & 0.123 & 0.087 \\
\hline & 0.6 & 0.181 & 0.092 & 0.090 \\
\hline & 0.7 & 0.151 & 0.069 & 0.082 \\
\hline & 0.8 & 0.123 & 0.047 & 0.076 \\
\hline & 0.9 & 0.117 & 0.018 & 0.099 \\
\hline & 0.1 & 0.206 & 0.228 & -0.022 \\
\hline \multirow{8}{*}{$(N=2,445)$} & 0.2 & 0.191 & 0.194 & -0.003 \\
\hline & 0.3 & 0.183 & 0.178 & 0.006 \\
\hline & 0.4 & 0.182 & 0.166 & 0.016 \\
\hline & 0.5 & 0.180 & 0.149 & 0.031 \\
\hline & 0.6 & 0.164 & 0.112 & 0.052 \\
\hline & 0.7 & 0.144 & 0.074 & 0.071 \\
\hline & 0.8 & 0.124 & 0.051 & 0.073 \\
\hline & 0.9 & 0.115 & 0.018 & 0.097 \\
\hline
\end{tabular}

Note: Table presents quantile decomposition results based on the procedure developed by Chernozhukov, Fernandez-Val, and Melly (2008). Reference group is male. Sample corresponds to Table 6, panel A, row (ii). 
Table A.3

Probability of being employed in a public sector job.

\begin{tabular}{|c|c|c|c|c|c|}
\hline & (i) All & $\begin{array}{l}\text { (ii) Economics } \\
\text { /business }\end{array}$ & (iii) STEM & $\begin{array}{l}\text { (iv) } \\
\text { Humanities }\end{array}$ & $\begin{array}{l}\text { (v) Medical } \\
\text { studies }\end{array}$ \\
\hline Female & $\begin{array}{l}0.042 \\
(0.005)^{* * * *}\end{array}$ & $\begin{array}{l}0.020 \\
(0.009)^{* *}\end{array}$ & $\begin{array}{l}0.080 \\
(0.010)^{* * *}\end{array}$ & $\begin{array}{l}-0.002 \\
(0.051)\end{array}$ & $\begin{array}{l}0.004 \\
(0.023)\end{array}$ \\
\hline State FE, cohort FE & Yes & Yes & Yes & Yes & Yes \\
\hline Age, family background & Yes & Yes & Yes & Yes & Yes \\
\hline Final second. school grade & Yes & Yes & Yes & Yes & Yes \\
\hline Field of study FE & Yes & Yes & Yes & Yes & Yes \\
\hline University FE & Yes & Yes & Yes & Yes & Yes \\
\hline$N$ & 20253 & 4024 & 7123 & 622 & 542 \\
\hline Mean dependent variable & 0.127 & 0.069 & 0.097 & 0.241 & 0.057 \\
\hline
\end{tabular}

Notes: Dependent variable takes value 1 if individual is employed in a public sector job, and 0 otherwise. Sample of full-time workers, excluding individuals who are in further training or in Ph.D. programs. See text for details.

\section{References}

Adda, J., Dustmann, C., Stevens, K., 2017. The career costs of children. J. Polit. Econ. 125 (2), 293-338.

Albrecht, J., Björklund, A., Vroman, S., 2003. Is there a glass ceiling in Sweden? J. Labor Econ. 21 (1), 145-177.

Albrecht, J., Bronson, M.A., Thoursie, P.S., Vroman, S., 2017. The Career Dynamics of High-Skilled Women and Men: Evidence from Sweden. Mimeo, Georgetown University.

Altonji, J.G., Blank, R., 1999. Race and gender in the labor market. In: Ashenfelter, O., Card, D. (Eds.), Handbook of Labor Economics, 3C. Elsevier, Amsterdam, pp. 3144-3259.

Angelov, N., Johannson, P., Lindahl, E., 2016. Parenthood and the gender gap in pay. J. Labor Econ. 34 (4), 545-579.

Antonczyk, D., Fitzenberger, B., Sommerfeld, K., 2010. Rising wage inequality, the decline of collective bargaining, and the gender wage gap. Labour Econ. 17 (5). 835-47

Arulampalam, W., Booth, A., Bryan, M., 2007. Is there a glass ceiling over Europe? Exploring the gender pay gap across the wage distribution. Indust. Labor Relat. Rev. 60 (2), 163-186.

Bertrand, M., 2010. New perspectives on gender. In: Ashenfelter, O., Card, D. (Eds.), Handbook of Labor Economics, 4B. Elsevier, Amsterdam, pp. 1545-1592.

Bertrand, M., Duflo, E., 2017. Field experiments on discrimination. In: Banerjee, A., Duflo, E. (Eds.), Handbook of Field Experiments, 1. Elsevier, Amsterdam, pp. 309-393.

Bertrand, M., Goldin, C., Katz, L.F., 2010. Dynamics of the gender gap for young professionals in the financial and corporate sectors. Am. Econ. J. Appl. Econ. $2(3), 228-255$.

Bertrand, M., Hallock, K.F., 2001. The gender gap in top corporate jobs. Indust. Labor Relat. Rev. 55 (1), 3-21.

Black, S.E., Spitz-Oener, A., 2010. Explaining womens success: Technological change and the skill content of womens work. Rev. Econ. Stat. 92 (1), $187-194$.

Blau, F.D., Kahn, L.M., 2003. Understanding international differences in the gender pay gap. J. Labor Econ. 21 (1), 106-144.

Blau, F.D., Kahn, L.M., 2017. The gender wage gap: extent, trends, and explanations. J. Econ. Literat. 55 (3), 789-865.

BMBF, 2017. Bundesministerium für Bildung und Forschung. http://www.datenportal.bmbf.de/portal/de/K2.html.

Booth, A.L., Francesconi, M., Frank, J., 2003. A sticky floor model of promotion, pay, and gender. Eur. Econ. Rev. 47 (2), 295-322.

Britton, J., Dearden, L., Shephard, N., Vignoles, A., 2016. How English domiciled graduate earnings vary with gender, institution attended, subject and socioeconomic background. IFS Working Paper W16/06.

Bundestag, D., 2017. Basic law for the Federal Republic of Germany. Print version, last amended on 23 December 2014, available online at https://www. btg-bestellservice.de/pdf/80201000.pdf.

Buser, T., Niederle, M., Oosterbeek, H., 2014. Gender, competitiveness, and career choices. Q. J. Econ. 129 (3), 1409-1447.

Bütikofer, A., Jensen, S., Salvanes, K.G., 2017. What Explains the Gender Gap among Top Earners. Mimeo.

Canon, M., Golan, L., 2017. Experience, Learning, and Occupation Choice: What Explains the Gender Earnings Gap?. Mimeo, Department of Economics, Washington University in St. Louis.

Chernozhukov, V., Fernández-Val, I., Melly, B., 2013. Inference on counterfactual distributions. Econometrica 81 (6), 2205-2268.

Christofides, L.N., Polycarpou, A., Vrachimis, K., 2013. Gender wage gaps, sticky floors and glass ceilings in Europe. Labour Econ. 21, 86-102.

Destatis, 2017. Studienanfänger ab WS 1947/48. German Statistical Office, Unit H 201.

Dustmann, C., Fitzenberger, B., Schönberg, U., Spitz-Oener, A., 2014. From the sick man of Europe to the economic superstar: Germany's resurgent economy. J. Econ. Perspect. 28 (1), 167-188.

Dustmann, C., Puhani, P., Schönberg, U., 2017. The long-term effects of early track choice. Econ. J. 127 (603), 1348-1380.

Fitzenberger, B., Sommerfeld, K., Steffes, S., 2013. Causal effects on employment after first birth: a dynamic treatment approach. Labour Econ. 25 (1), $49-62$.

Fitzenberger, B., Wunderlich, G., 2002. Gender wage differences in West Germany: a cohort analysis. German Econ. Rev. 3 (4), 379-414.

Fortin, N.M., 2008. The gender wage gap among young adults in the United States: The importance of money versus people. J. Hum. Res. 43 (4), $884-918$.

Federal Anti-Discrimination Agency, 2017. Guide to the general equal treatment act. Explanations and Examples. Available online at http: //www.antidiskriminierungsstelle.de/SharedDocs/Downloads/EN/publikationen/agg_wegweiser_engl_guide_to_the_general_equal_treatment_act.pdf? blob=publicationFile\&v=1.

Fortin, N.M., Oreopoulos, P., Phipps, S., 2015. Leaving boys behind: gender disparities in high academic achievement. J. Hum. Resour. 50 (3), 549-579.

Gallego-Granados, P., Geyer, J., 2015. Distributional and Behavioral Effects of the Gender Wage Gap. DIW Berlin, German Institute for Economic Research. Discussion Paper 1469.

Gayle, G.-L., Golan, L., 2012. Estimating a dynamic adverse-selection model: labour-force experience and the changing gender earnings gap 1968-1997. Rev. Econ. Stud. 79 (1), 227-267.

Goldin, C., Katz, L.F., 2008. Transitions: career and family lifecycles of the educational elite. Am. Econ. Rev. 98 (2), 363-369.

Goldin, C., Katz, L.F., 2016. A most egalitarian profession: pharmacy and the evolution of a family friendly occupation. J. Labor Econ. 34 (3), $705-746$.

Goldin, C., Mitchell, J., 2017. The new life cycle of women's employment: disappearing humps, sagging middles, expanding tops. J. Econ. Perspect. 31 (1), $161-182$.

Grotheer, M., Isleib, S., Netz, N., Briedis, K., 2012. Hochqualifiziert und gefragt: Ergebnisse der zweiten HIS-HF Absolventenbefragung des Jahrgangs 2005. HIS: Forum Hochschule. November, 2012 (14).

Heublein, U., Richter, J., Schmelzer, R., Sommer, D., 2012. Die Entwicklung der Schwund- und Studienabbruchquoten an den deutschen Hochschulen. statistische Berechnungen auf der Basis des Absolventenjahrgangs 2010. HIS: Forum Hochschule 2012 (3).

Huffman, M.L., King, J., Reichelt, M., 2017. Equality for whom? Organizational policies and the gender gap across the german earnings distribution. Indust. Labor Relat. Rev. 70 (1), 16-41. 
Juhn, C., McCue, K., 2017. Specialization then and now: Marriage, children, and the gender earnings gap across cohorts. J. Econ. Perspect. 31 (1), $183-204$. Kirkeboen, L., Leuven, E., Mogstad, M., 2016. Field of study, earnings, and self-selection. Q. J. Econ. 131 (3), $1057-1111$.

Lazear, E.P., Rosen, S., 1990. Male-female wage differentials in job ladders. J. Labor Econ. 8 (1, Pt. 2), S106-S123.

Leuze, K., Strauß, S., 2009. Wage inequality between male and female university graduates: The influence of occupational specialization, female-dominated subjects and occupational segregation. Z. Soziol. 38 (4), 262-281. (in German).

Liu, K., 2016. Explaining the gender wage gap: Estimates from a dynamic model of job changes and hours changes. Q. Econ. 7 (2), $411-447$.

Machin, S., Puhani, P.A., 2003. Subject of degree and the gender wage differential: Evidence from the UK and Germany. Econ. Lett. 79 (3), 393-400.

Maier, F., 2007. The persistence of the gender wage gap in Germany. The Harriet Taylor Mill Institute for Economic and Gender Studies. Discussion Paper $01,12 / 2007$.

Mas, A., Pallais, A., 2017. Valuing alternative work arrangements. Am. Econ. Rev. 107 (12), 3722-3759.

Niederle, M., Vesterlund, L., 2011. Gender and competition. Annu. Rev. Econ. 3, 601-630.

OECD, 2015. Education at a Glance 2015: OECD Indicators. OECD Publishing, Paris.

Olivetti, C., Petrongolo, B., B., 2016. The evolution of gender gaps in industrialized countries. Annual Review of Economics 8 (1), $405-434$.

Parey, M., Ruhose, J., Waldinger, F., Netz, N., 2017. The selection of high-skilled emigrants. Rev. Econ. Stat. 99 (5), $776-792$.

Parey, M., Waldinger, F., 2011. Studying abroad and the effect on international labour market mobility: evidence from the introduction of ERASMUS. Econ. J. 121 (551), 194-222.

Pekkarinen, T., 2008. Gender differences in educational attainment: evidence on the role of tracking from a Finnish quasi-experiment. Scand. J. Econ. 110 (4), 807-825.

Philippon, T., Reshef, A., 2012. Wages and human capital in the U.S. finance industry: 1909-2006. Q. J. Econ. 127 (4), $1551-1609$.

Reuben, E., Sapienza, P., Zingales, L., 2014. How stereotypes impair women's careers in science. Proc, Natl. Acad. Sci. 111 (12), $4403-4408$.

Reuben, E., Wiswall, M., Zafar, B., 2017. Preferences and biases in educational choices and labour market expectations: shrinking the black box of gender. Econ. J. 127 (604), 2153-2186.

Sasser, A.C., 2005. Gender differences in physician pay: tradeoffs between career and family. J. Hum. Res. 40 (2), $477-504$.

Schönberg, U., Ludsteck, J., 2014. Expansions in maternity leave coverage and mothers labor market outcomes after childbirth. J. Labor Econ. 32 (3), $469-505$. Thomas, M., 2018. The Impact of Mandated Maternity Benefits on the Gender Differential in Promotions: Examining the Role of Adverse Selection. Mimeo, University of Chicago.

Wiswall, M., Zafar, B., 2015. Determinants of college major choice: Identification using an information experiment. Rev. Econ. Stud. 82 (2), $791-824$.

Wiswall, M., Zafar, B., 2018. Preference for the workplace, investment in human capital, and gender. Q. J. Econ 133 (1), $457-507$.

Wolfers, J., 2006. Diagnosing discrimination: stock returns and CEO gender. J. Eur. Econ. Assoc. 4 (2-3), 531-541.

Wood, R.G., Corcoran, M.E., Courant, P.N., 1993. Pay differences among the highly paid: the male-female earnings gap in lawyers' salaries. J. Labor Econ. 11 (3), 417-441. 